Nature geoscience

April 2015, Volume 8, Issue 4, Pages 299-304

http://dx.doi.org/10.1038/ngeo2387

http://archimer.ifremer.fr/doc/00255/36658/

(c) 2015 Macmillan Publishers Limited. All Rights Reserved.

\title{
Presence of oxygen and aerobic communities from sea floor to basement in deep-sea sediments
}

\author{
D'Hondt Steven ${ }^{1}{ }^{\star}$, Inagaki Fumio ${ }^{2}$, Alvarez Zarikian Carlos ${ }^{3}$, Abrams Lewis J. ${ }^{4}$, Dubois Nathalie ${ }^{5}$, \\ Engelhardt Tim ${ }^{6}$, Evans Helen ${ }^{3}$, Ferdelman Timothy ${ }^{7}$, Gribsholt Britta ${ }^{8}$, Harris Robert N. ${ }^{9}$, \\ Hoppie Bryce W. ${ }^{10}$, Hyun Jung-Ho ${ }^{11}$, Kallmeyer Jens ${ }^{12}$, Kim Jinwook ${ }^{13}$, Lynch Jill E. ${ }^{14}$, \\ Mckinley Claire C. ${ }^{15}$, Mitsunobu Satoshi ${ }^{16}$, Morono Yuki ${ }^{2}$, Murray Richard W. '17, Pockalny Robert ${ }^{1}$, \\ Sauvage Justine ${ }^{1}$, Shimono Takaya ${ }^{18}$, Shiraishi Fumito ${ }^{19}$, Smith David C. ${ }^{1}$, \\ Smith Duke Christopher E. ${ }^{20}$, Spivack Arthur J. ${ }^{1}$, Steinsbu Bjorn Olav ${ }^{21}$, Suzuki Yohey ${ }^{22}$, \\ Szpak Michal ${ }^{23}$, Toffin Laurent ${ }^{24}$, Uramoto Goichiro ${ }^{2}$, Yamaguchi Yasuhiko T. ${ }^{22}$, Zhang Guo-Liang ${ }^{25}$, \\ Zhang Xiao-Hua ${ }^{26}$, Ziebis Wiebke ${ }^{27}$
}

${ }^{1}$ Graduate School of Oceanography, University of Rhode Island, 215 South Ferry Road Narragansett, Rhode Island 02882, USA

${ }^{2}$ Kochi Institute for Core Sample Research, Japan Agency for Marine-Earth Science and Technology, Monobe B200, Nankoku Kochi 783-8502, Japan

${ }^{3}$ International Ocean Discovery Program, Texas A\&M University, 1000 Discovery Drive, College Station Texas 77845-9547, USA

${ }^{4}$ Center for Marine Science, University of North Carolina at Wilmington, 5600 Marvin K. Moss Lane Wilmington, North Carolina 28409, USA

${ }^{5}$ Swiss Federal Institute of Aquatic Science and Technology, Ueberlandstrasse 1338600 Duebendorf, Switzerland

${ }^{6}$ Institut für Chemie und Biologie Des Meeres, Carl von Ossietzky Universität Oldenburg, Oldenburg 26129, Germany

${ }^{7}$ Department of Biogeochemistry, Max-Planck-Institute of Marine Microbiology, Celsiusstrasse 1, 28359 Bremen, Germany

${ }^{8}$ Center for Geomicrobiology, Aarhus Universitet, Ny Munkegade 114, Building 15408000 Aarhus, Denmark

${ }^{9}$ College of Earth, Oceanic, and Atmospheric Sciences, Oregon State University, 104 COAS Admin Building Corvallis, Oregon 97331-5503, USA

${ }^{10}$ Minnesota State University, Mankato, Department of Chemistry and Geology, Ford Hall 241, Mankato Minnesota 56001, USA

${ }^{11}$ Department of Marine Sciences and Convergent Technology, Hanyang University, 1271 Sa-3 dong, Ansan Gyeonggi-do 426-791, Korea

${ }^{12}$ GFZ German Research Centre for Geosciences, Section 4.5 Geomicrobiology, Telegrafenberg, 14473 Potsdam, Germany

${ }^{13}$ Earth Systems Sciences, Yonsei University, 134 Shinchon dong 120-749 Seoul, Korea

${ }^{14}$ School of Earth Sciences, University of Melbourne, McCoy Building Melbourne, Victoria 3010, Australia

${ }^{15}$ Department of Oceanography, Texas A\&M University, College Station Texas 77843, USA

${ }^{16}$ Institute for Environmental Sciences, Shizuoka University, 52-1 Yada Suruuga-ku, Shizuoka 4228526, Japan

${ }^{17}$ Department of Earth and Environment, Boston University, 675 Commonwealth Avenue Boston, Massachusetts 02215, USA

${ }^{18}$ Graduate School of Life and Environmental Sciences, University of Tsukuba, 1-1-1 Tennoudai 
Tsukuba, Ibaraki 305-8572, Japan

${ }^{19}$ Graduate School of Science, Hiroshima University, 1-3-1 Kagamiyama, Higashi-Hiroshima Hiroshima 739-8526, Japan

${ }^{20}$ National Oceanography Centre, University of Southampton, European Way Southampton SO14 3ZH, UK

${ }^{21}$ Department of Earth Science, University of Bergen, Allegaten 415007 Bergen, Norway

${ }^{22}$ Earth and Planetary Science Department, Graduate School of Science, The University of Tokyo, 7-31 Hongo Bunkyo-ku, Tokyo 113-0033, Japan

${ }^{23}$ School of Chemical Sciences, Dublin City University, Collins Avenue Glasnevin, Dublin 9, Ireland

${ }^{24}$ Institut Français de Recherche pour l'Exploitation de la Mer, Centre Bretagne, CS 1007029280 Plouzané, France

${ }^{25}$ South China Sea Institute of Oceanology, Chinese Academy of Sciences, 7 Nanhai Road, Shinan Region Qingdao 266071, China

${ }^{26}$ College of Marine Life Sciences, Ocean University of China, 5 Yushan Road Qingdao 266003, China

${ }^{27}$ Department of Biological Sciences, University of Southern California, 3616 Trousdale Boulevard, AHF 335 Los Angeles, California 90089, USA

* Corresponding author : Steven D'Hondt, email address : $\underline{\text { dhondt@mail.uri.edu }}$

\begin{abstract}
:
The depth of oxygen penetration into marine sediments differs considerably from one region to another. In areas with high rates of microbial respiration, $\mathrm{O} 2$ penetrates only millimetres to centimetres into the sediments, but active anaerobic microbial communities are present in sediments hundreds of metres or more below the sea floor. In areas with low sedimentary respiration, O2 penetrates much deeper but the depth to which microbial communities persist was previously unknown. The sediments underlying the South Pacific Gyre exhibit extremely low areal rates of respiration. Here we show that, in this region, microbial cells and aerobic respiration persist through the entire sediment sequence to depths of at least 75 metres below sea floor. Based on the Redfield stoichiometry of dissolved $\mathrm{O} 2$ and nitrate, we suggest that net aerobic respiration in these sediments is coupled to oxidation of marine organic matter. We identify a relationship of $\mathrm{O} 2$ penetration depth to sedimentation rate and sediment thickness. Extrapolating this relationship, we suggest that oxygen and aerobic communities may occur throughout the entire sediment sequence in $15-44 \%$ of the Pacific and $9-37 \%$ of the global sea floor. Subduction of the sediment and basalt from these regions is a source of oxidized material to the mantle.
\end{abstract}

\title{
Main
}

Morita and ZoBell nearly 60 years ago reported "the lower limits of the biosphere" at 3.9 to 7.5 meters below seafloor (mbsf) in abyssal clay of the oligotrophic North Pacific Gyre (NPG) ${ }^{17}$. Recent studies pushed the lower limit of the known sedimentary biosphere to slightly greater depths in abyssal clay of oligotrophic regions; microbial cells have been identified at $8 \mathrm{mbsf}$ in the ultra-oligotrophic South Pacific Gyre (SPG) 5 and $20 \mathrm{mbsf}$ in the NPG6, and aerobic respiration has been inferred to nearly $30 \mathrm{mbsf}$ in the NPG6. However, the existence, nature and consequences of life at greater sedimentary depths in the oligotrophic ocean have remained unknown.

To document the nature of life and habitability in the deepest abyssal sediment of a major low-productivity oceanic region, we undertook Integrated Ocean Drilling Program (IODP) Expedition 329 to the South Pacific Gyre (Oct-Dec 2010)7. The SPG is Earth's largest oligotrophic ocean region, covering $\sim 10 \%$ of Earth's surface. Oxygen flux across the SPG seafloor is extremely low ${ }^{18}$. Mean sedimentation rate, surface chlorophyll concentrations and primary productivity are lower in the SPG than in any other oceanic region5. Shallow cores in abyssal sediment of the SPG exhibit the lowest seafloor cell concentrations and the lowest areal 
32 rates of microbial activity ever previously encountered in marine sediment ${ }^{5,19}$.

33 Six of the seven Expedition 329 sites are located in the low-chlorophyll SPG (U1365-

34 U1370), and one is located in the more biologically productive region south of the SPG (U1371)

35 (Fig 1) ${ }^{7}$. These sites range in water depth from 3740 meters below sea level (mbsl) (U1368) to

$365695 \mathrm{mbsl}$ (U1365) (SI). Sediment temperature $\left(1.1^{\circ}-10.6^{\circ} \mathrm{C}\right)$ is habitable by psychrophiles at

37 all sites ${ }^{7}$. Basement age ranges from 13.5 Ma (U1368) to 84-120 Ma (U1365 and U1366) (SI).

38 Sediment thickness co-varies with basement age and is lower at the SPG sites (16-75 m) than at

39 Site U1371 south of the SPG $(131 \mathrm{~m})^{7}$. Site U1370 migrated into the gyre from the southern

40 biologically productive region between 20 and 30 myrs ago (Fig 1$)^{7}$. The other sites have resided

41 within the low-chlorophyll region for most or all of their history.

42 Microbial cells are present throughout the entire sediment sequence at all seven sites. At the

43 six SPG sites (U1365-U1370), cell counts are extremely low and decrease with increasing

44 sediment depth (Fig 2). They are one to seven orders of magnitude lower than counts at the same

45 depths in previously drilled sites of ocean margins and upwelling regions ${ }^{19}$. They are up to two

46 orders of magnitude lower than cell counts in piston-cored sediment of the oligotrophic NPG ${ }^{19}$.

47 Site U1371, in the higher productivity region south of the gyre, is characterized by cell counts

48 that are generally higher than at the SPG sites between 0 and 40 mbsf (Fig 2); at greater depths,

49 they converge with the SPG counts.

50 At the six sites within the SPG, dissolved $\mathrm{O}_{2}$ is present from the seafloor to the sediment-

51 basement interface (Fig 2) ${ }^{7}$. Dissolved $\mathrm{O}_{2}$ persists even in the deepest sediment at U1365 (62 to

$5275 \mathrm{mbsf}$ ) despite an intervening 20-m layer of chert ${ }^{7}$. Persistence of dissolved $\mathrm{O}_{2}$ throughout

53 the SPG sediment sequence is consistent with the much earlier discovery that dissolved nitrate

$54\left(\mathrm{NO}_{3}^{-}\right)$is at or above deep-water concentrations throughout the entire sediment column of Deep 
55 Sea Drilling Project Leg 92 sites elsewhere in the $\mathrm{SPG}^{20}\left(\mathrm{NO}_{3}{ }^{-}\right.$reduction does not occur until

56 most or all $\mathrm{O}_{2}$ is depleted ${ }^{21}$ ). Because dissolved $\mathrm{O}_{2}$ is present in the deepest sediment, it must

57 also be present in the basement aquifer in diffusive contact with this sediment. This discovery ${ }^{7}$

58 greatly expands the subsurface envelope of the oxic realm to include the entire sedimentary

59 sequence and the upper basaltic basement throughout the entire SPG.

60 In oceanic regions where dissolved $\mathrm{O}_{2}$ penetrates only $\mathrm{mm}$ to decimeters into the sediment,

61 the sediment is exposed to $\mathrm{O}_{2}$ for a very short time (years to kyrs) before it enters a deep anoxic

62 realm ${ }^{22}$. In contrast, SPG sediment is exposed to dissolved $\mathrm{O}_{2}$ for an extraordinarily long time,

63 and never becomes anoxic. Because $\mathrm{O}_{2}$ penetrates the entire sedimentary sequence, $\mathrm{O}_{2}$ exposure

64 time for SPG sediment is formally equal to the age of the oldest sediment at each site, implying

65 that SPG sediment is continuously exposed to $\mathrm{O}_{2}$ for its entire history (up to 120 myrs at Site

66 U1365) (SI).

67 In comparison, dissolved $\mathrm{O}_{2}$ is absent from most of the sediment column at U1371, in the

68 moderately productive subtropical convergence south of the SPG (Fig 1) ${ }^{7}$. At this site, $\mathrm{O}_{2}$

69 diffusing down from the ocean decreases below detection within 0.9 mbsf and traces of $\mathrm{O}_{2}$

70 penetrate $\sim 15$ meters upward into the sediment from the underlying basaltic aquifer. Oxygen

71 exposure time for the shallow sediment at U1371 is only $35 \mathrm{kyrs}$ (SI).

72 The presence of dissolved $\mathrm{O}_{2}$, nitrate $\left(\mathrm{NO}_{3}{ }^{-}\right)$, phosphate $\left(\mathrm{PO}_{4}^{-}\right)$and dissolved inorganic

73 carbon $\left(\mathrm{DIC}=\mathrm{CO}_{3}{ }^{2-}+\mathrm{HCO}_{3}{ }^{-}+\mathrm{CO}_{2}\right)$ throughout the sediment of SPG sites U1365-U1370 (Fig

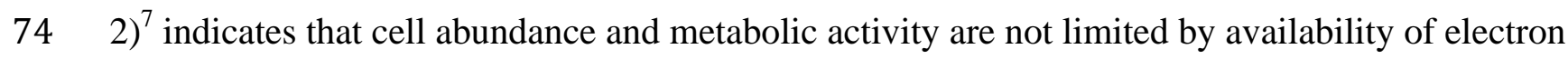

75 acceptors or dissolved major inorganic nutrients $(\mathrm{C}, \mathrm{N}, \mathrm{P})$ in the sediment or the upper basaltic

76 basement. Concentration profiles of the dissolved metabolic products $\mathrm{PO}_{4}{ }^{-}$, DIC, and, at Site

$77 \mathrm{U} 1370, \mathrm{NO}_{3}{ }^{-}$exhibit more complexity than dissolved $\mathrm{O}_{2}$ profiles and the other $\mathrm{NO}_{3}{ }^{-}$profiles, 
78 because DIC and, at $\mathrm{U} 1370, \mathrm{NO}_{3}{ }^{-}$are affected by loss to the basement and $\mathrm{PO}_{4}{ }^{-}$and DIC interact 79 with sedimentary minerals.

80 Dissolved $\mathrm{NO}_{3}$ is produced in the sediment by aerobic degradation and subsequent

81 nitrification of nitrogen from buried organic matter ${ }^{21}$. Downhole changes in dissolved $\mathrm{NO}_{3}{ }^{-}$and

$82 \mathrm{O}_{2}$ concentrations closely match the Redfield $\mathrm{NO}_{3}^{-}: \mathrm{O}_{2}$ ratio $(16:-170)^{23}$, suggesting that net $\mathrm{O}_{2}$

83 reduction is almost solely due to oxidation of buried organic matter (SI).

84 Analysis of undisturbed coring intervals indicates that net $\mathrm{O}_{2}$ reduction occurs throughout the 85 entire sedimentary sequence at very low rates (Fig 3) (SI). Net $\mathrm{O}_{2}$ consumption is highest in the 86 first 1.1 to $2.3 \mathrm{mbsf}$ of the SPG sites, ranging from $6.3 * 10^{-11}$ moles $\mathrm{O}_{2} / \mathrm{cm}^{3} / \mathrm{yr}$ at U1366 to $875.3^{*} 10^{-10}$ moles $/ \mathrm{cm}^{3} / \mathrm{yr}$ at U1367 (Fig 3). These rates are considerably lower than rates reported 88 from equivalent depths in sediment of the oligotrophic NPG $\left(10^{-7} \mathrm{moles}_{2} / \mathrm{cm}^{3} / \mathrm{yr}\right)^{6}$. With 89 increasing depth, the rate of net $\mathrm{O}_{2}$ consumption rapidly decreases to even lower values. It is 90 generally indistinguishable from zero in zones that span intervals of drilling disturbance (Fig 3).

91 In the undisturbed sediment, net $\mathrm{O}_{2}$ consumption rates are generally distinguishable from zero 92 and range from $3.3 * 10^{-13}$ moles $\mathrm{O}_{2} / \mathrm{cm}^{3} / \mathrm{yr}$ at $\mathrm{U} 1370$ (37.5 to $68 \mathrm{mbsf}$ ) to $1.5^{*} 10^{-11}$ moles $93 \mathrm{O}_{2} / \mathrm{cm}^{3} / \mathrm{yr}$ at U1365 (4.9 to $8.8 \mathrm{mbsf}$ ) (Fig 3) (SI).

94 Within the SPG, depth-integrated subseafloor net $\mathrm{O}_{2}$ reduction rates (from $1.5 \mathrm{mbsf}$ to 95 sediment-basalt interface) decrease from gyre edge to gyre center, in parallel with seasurface 96 chlorophyll content (SI). Peak concentrations of dissolved $\mathrm{PO}_{4}^{-}$, DIC and TOC are also 97 consistent with organic-fueled subseafloor respiration declining from outside the gyre (U1371) to 98 gyre center (U1368) (Fig 2).

99 Gross rates of $\mathrm{O}_{2}$ consumption presumably exceed these organic-fueled rates of net $\mathrm{O}_{2}$

100 reduction, because in situ water radiolysis generates both $\mathrm{H}_{2}$ and $\mathrm{O}_{2}$ in marine sediment ${ }^{24}$ and 
101 most $\mathrm{H}_{2}$ produced in SPG sediment is quickly consumed (concentrations of dissolved $\mathrm{H}_{2}$ at these

102 sites are generally below $1 \mathrm{nM}$ and never exceed $90 \mathrm{nM})^{7}(\mathrm{SI})$. The Redfield stoichiometry of $\mathrm{O}_{2}$

103 reduction to $\mathrm{NO}_{3}{ }^{-}$production in SPG sediment suggests that radiolytic production of $\mathrm{O}_{2}$ does not

104 significantly contribute to the dissolved $\mathrm{O}_{2}$ concentrations (perhaps because $\mathrm{H}_{2}$ is kept at low

105 concentrations by reactions that reverse radiolytic production of $\mathrm{H}_{2}, \mathrm{O}_{2}$ and $\mathrm{H}_{2} \mathrm{O}_{2}$, such as the

106 microbially mediated Knallgas reaction).

107 Mean organic-fueled respiration per cell in the shallowest SPG sediment (1.6-2.3 mbsf) is in

108 the range of $1.2^{*} 10^{-15}$ moles e $/$ cell/year (U1365) to $1.1 * 10^{-14}$ moles e $/$ cell/year (U1366). Mean

109 organic-fueled per-cell respiration is generally even lower at greater depths; in intervals where

110 the volumetric $\mathrm{O}_{2}$ consumption rate is distinguishable from zero, mean organic-fueled per-cell

111 respiration is between $3.2 * 10^{-17}$ moles $\mathrm{e}^{-} / \mathrm{cell} / \mathrm{year}$ and $6.8 * 10^{-14}$ moles $\mathrm{e}^{-/ c e l l} / \mathrm{year}$. These rates at

112 greater depths overlap with mean per-cell respiration rates reported for deep subseafloor aerobes

113 in the North Pacific Gyre $\left(1.5^{*} 10^{-15} \text { moles e }{ }^{-} / \text {cell/year }\right)^{6}$. The rates from SPG depths where $\mathrm{O}_{2}$

114 consumption is distinguishable from zero generally exceed mean per-cell rates of deep

115 subseafloor anaerobes in eastern equatorial Pacific sediment $\left[2.8^{*} 10^{-18}\right.$ to $1.7 * 10^{-17}$ moles e-

116 /cell/year (SI)].

117 These per-cell rates of organic-fueled respiration are broadly consistent with the general

118 interpretation that microbial respiration rates are extraordinarily low in subseafloor sediment ${ }^{25,5}$,

$1196,13,16$. Nevertheless, estimates of per-cell rates must be treated with caution for the following

120 reasons: (i) the ratio of active cells to dead or moribund cells in counted populations is not yet

121 known, and (ii) the contribution of radiolytic $\mathrm{H}_{2}$ oxidiation to microbial respiration in SPG

122 sediment is also unknown.

123 The primary driver of the reductions in cell abundance and net (organic-fueled) $\mathrm{O}_{2}$ reduction 
124 with increasing sediment depth at SPG sites (U1365-U1370) appears to be decreasing

125 availability of organic matter with increasing sediment age. Total organic carbon (TOC) content

126 decreases rapidly with sediment depth, from values between $0.08 \%$ (U1368) and $0.25 \%$ (U1370)

127 in the first centimeters below seafloor to stable values of "below detection" $(0.002 \%)$ to $0.03 \%$ at

128 greater depths (Fig 2). This decrease in TOC with increasing depth is primarily due to

129 consumption within the sediment; as the sediment ages, less TOC remains to be consumed ${ }^{26}$.

130 Total organic carbon approaches our detection limit deep in the sediment at all six SPG sites,

131 including U1370 (Fig 2), which migrated through the higher productivity region south of the

132 SPG early in its history (Fig 1). In comparison, TOC is greater than $0.1 \%$ through the upper 100

133 mbsf at Site U1371 (south of the SPG) and greater than 1.0\% for hundreds of mbsf at some

134 ocean-margin sites ${ }^{27}$.

135 Depth of $\mathrm{O}_{2}$ penetration ultimately depends on the balance between supply of reduced

136 oxidizable material (primarily organic matter) and supply of dissolved $\mathrm{O}_{2}{ }^{1}$. In near-seafloor

137 sediment, organic flux to the seafloor exerts primary control ${ }^{28}$. The situation becomes more

138 complicated as sediment depth and age increase, because (i) the supply of organic matter at depth

139 in sediment depends on both the initial flux of reduced material to the seafloor and the

140 subsequent oxidation history of that material at successively greater sediment depths, and (ii) the

141 timescale required for diffusion (e.g., of dissolved $\mathrm{O}_{2}$ ) depends on the square of the distance

142 penetrated $^{29}$.

143 Comparison of our SPG results to other sites indicate that dissolved $\mathrm{O}_{2}$ penetrates the entire

144 sediment column at sites with low mean sediment accumulation rates and relatively thin

145 sediment thickness (Fig 4) (SI). This result is consistent with the complexities outlined above.

146 Dependence of $\mathrm{O}_{2}$ penetration depth on sediment accumulation rate is consistent with depth of 
$147 \mathrm{O}_{2}$ penetration depending on organic burial rate; organic flux to the seafloor broadly co-varies

148 with sedimentation rate ${ }^{18}$ and at very low sediment accumulation rates, most organic matter is

149 consumed at or near the seafloor and very little remains to be buried ${ }^{30,6}$. Dependence of $\mathrm{O}_{2}$

150 penetration depth on sediment thickness is consistent with the exponential effect of diffusive

151 distance on diffusive timescale; as sediment thickness increases, $\mathrm{O}_{2}$ disappears faster than it can

152 diffuse to the greatest depths.

153 Our results have significant implications for the nature and global distribution of subseafloor

154 life. The persistence of microbial cells and aerobic respiration throughout the entire sediment

155 sequence indicates that there is no depth limit to the biosphere within the sediment of the most

156 oligotrophic ocean region. If active microbial communities and $\mathrm{O}_{2}$ penetrate to basement

157 throughout the regions shown in figure 4, an aerobic ecosystem is present throughout the

158 sediment column and the upper basement over $15-44 \%$ of the Pacific seafloor and 9-37\% of the

159 entire ocean (Fig 4) (SI).

160 Throughout this vast area of $\mathrm{O}_{2}$ penetration to basement, the predominant microbial activities

161 are aerobic throughout the sediment column, subseafloor rates of organic-fueled respiration and

162 cell abundances are extremely low, and sedimentary oxygen exposure time equals basement age.

163 This large-scale pattern of subseafloor oxidation may ultimately affect the chemical

164 evolution of Earth's mantle and subduction-related volcanic systems. In subduction zones where

165 deep sediment and basalt of the sinking slab became anoxic early in their history, the principal

166 redox species in the upper portion of the sinking slab include reduced iron, reduced sulfur and

167 reduced organic carbon ${ }^{31}$. In contrast, in subduction zones where dissolved $\mathrm{O}_{2}$ penetrates (or long

168 penetrated) the sediment sequence and the upper basement (e.g., the Tonga Trench and the Peru-

169 Chile Trench), oxidized iron and manganese are abundant and reduced metal, reduced sulfur and 
170 reduced organic matter are largely absent in the upper portion of the sinking slab (SI). The redox

171 state of subducted material influences the extent of mantle oxidation ${ }^{32}$, which in turn affects

172 magmatic evolution, mineral assemblage and gas speciation in volcanic systems, and the long-

173 term evolution of atmospheric oxygen content ${ }^{31}$.

174 


\section{References}

1761 Emerson, S., K. Fischer, K., Reimers C., \& Heggie, D. Organic carbon dynamics and 177 preservation in deep-sea sediments. Deep-Sea Res. 32, 1-21 (1985).

1782 Jahnke, R.A., Heggie, D., Emerson, S. \& Grundmanis, V. Pore waters of the central 179 Pacific Ocean: Nutrient results. Earth Planet. Sci. Lett. 61, 233-256 (1982).

1803 Revsbech, N. P., Jørgensen, B. B. \& Blackburn, T. H. Oxygen in the sea bottom 181 measured with a microelectrode. Science 207, 1355-1356 (1980).

1824 Murray, J. W. \& Grundmanis, V. Oxygen consumption in pelagic marine sediments. $183 \quad$ Science 209, 1527-1530 (1980).

1845 D'Hondt, S. et al. Subseafloor sedimentary life in the South Pacific Gyre. Proc. Nat. 185 Acad. Sci. U.S.A. 106, 11651-11656, doi:10.1073/pnas.0811793106 (2009).

1866 Røy, H., Kallmeyer, J., Adhikari, R. R., Pockalny, R., Jørgensen, B. B. \& D’Hondt, S. 187 Aerobic microbial respiration in 86-million-year-old deep-sea red clay, Science 336 188 (6083), 922-925, DOI: 10.1126/science.1219424 (2012).

1897 D'Hondt, S., Inagaki, F., Alvarez Zarikian, C.A., and the Expedition 329 Scientists.

190 Proc. IODP, 329: Tokyo (Integrated Ocean Drilling Program Management

191 International, Inc.), doi:10.2204/ iodp.proc.329.2011 (2011).

1928 Orcutt, B. N. et al., Oxygen consumption rates in subseafloor basaltic crust derived from 193 a reaction transport model, Nat. Commun. 4, 2539, DOI: 10.1038/ncomms3539 (2013).

1949 Whelan, J. K. et al. Evidence for sulfate-reducing and methane-producing 195 microorganisms in sediments from Sites 618, 619 and 622, in Init. Repts. DSDP 96 (eds.

196 Bouma, A. H., Coleman, J. M., Meyer, A. W., et al.), 767-775 (U.S. Government Printing 197 Office, Washington D.C., 1986). 
19810 Parkes, R. J. et al. Deep bacterial biosphere in Pacific Ocean sediments. Nature 371, 410-

$199413(1994)$.

20011 Head, I. M., Jones, D. M. \& Larter, S. R. Biological activity in the deep subsurface and

201 the origin of heavy oil, Nature 626(6964), 344-352 (2003).

20212 D'Hondt, S. et al. Distributions of microbial activities in deep subseafloor sediments.

$203 \quad$ Science 306, 2216-2221 (2004).

20413 Schippers, A. et al. Prokaryotic cells of the deep sub-seafloor biosphere identified as

205 living bacteria. Nature 433, 861-864 (2005).

$20614 \quad$ Inagaki, F. et al. Biogeographical distribution and diversity of microbes in methane

207 hydrate-bearing deep marine sediments, on the Pacific Ocean Margin. Proc. Nat. Acad.

208 Sci. U.S.A. 103, 2815-2820 (2006).

20915 Batzke, A., Engelen, B., Sass, H. \& Cypionka, H. Phylogenetic and physiological

210 diversity of cultured deep-biosphere bacteria from Equatorial Pacific Ocean and Peru

211 Margin Sediments. Geomicrobiol. J. 24, 261-273 (2007).

$21216 \quad$ Lomstein, B.A., Langerhuus, A.T., D’Hondt, S., Jørgensen, B.B. \& Spivack, A.J. Spore

213 abundance, microbial growth and necromass turnover in deep subseafloor sediment,

$214 \quad$ Nature 484, 101-104 (2012).

21517 Morita, R.Y. \& Zobell, C.E., Occurrence of bacteria collected during the Mid-Pacific

216 Expedition, Deep-Sea Research 3, 66-73 (1955).

21718 Jahnke, R. A. The global ocean flux of particulate organic carbon: areal distribution 218 and magnitude. Global Biogeochem. Cycles 10, 71-88 (1996).

21919 Kallmeyer, J., Pockalny, R. Adhikari, R., Smith D. C. \& D’Hondt, S. Global distribution 220 of subseafloor sedimentary biomass, Proc. Nat. Acad. Sci. U.S.A. 109, 16213-16216 
(2012).

$222 \quad 20$

223

224

225

226

$227 \quad 22$

228

229

$230 \quad 23$

231

$232 \quad 24$

233

234

$235 \quad 25$

236

$237 \quad 26$

238

$239 \quad 27$

240

$241 \quad 28$

242

243

Gieskes, J. M. \& Boulegue, J. Interstitial Water Studies, Leg-92, Initial Reports of the Deep Sea Drilling Project 92, 423-429 (1986).

Hensen, C. \& Zabel, M. Early Diagenesis at the Benthic Boundary Layer: Oxygen and Nitrate in Marine Sediments, in Marine Geochemistry (eds. Schulz, H. D. \& Zabel, M.), Springer-Verlag (Berlin), 209-231 (2000).

Hedges, J.I., F.S. Hu, A.H. Devol, H.E. Hartnett, E. Tsamakis \& R.G. Keil, Sedimentary organic matter preservation: a test for selective degradation under oxic conditions, Am. J.

Sci. 299, 529-555 (1999).

Anderson, L. A. \& Sarmiento, J. L. Global ocean phosphate and oxygen simulations. Glob. Biogeochem. Cy. 9, 621-636 (1995).

Blair, C. C., D’Hondt, S., Spivack, A. J. \& Kingsley, R. H. Potential of radiolytic hydrogen for microbial respiration in subseafloor sediments, Astrobiol. 7(6), 951-970 (2007).

D'Hondt, S., Rutherford, S. \& Spivack, A. J. Metabolic activity of subsurface life in deep-sea sediments, Science 295, 2067-2070 (2002).

Middelburg, J.J., A simple rate model for organic matter decomposition in marine sediments, Geochim. Cosmochim. Ac. 53, 1577-1581 (1989).

Meister, P., Prokopenko, M., Skilbeck, C. G., Watson, M. \& McKenzie, J. in Proc. ODP, Sci. Results 201 (eds S.L. D'Hondt, B.B. Jørgensen, \& D.J. Miller) (2005).

Murray, J.W. \& Kuivila, K.M. Organic matter diagenesis in the northeast Pacific: Transition from aerobic red clay to suboxic hemipelagic sediments. Deep Sea Res. 37, 59-80 (1990). 
24429 Einstein, A., Über die von der molekularkinetischen Theorie der Wärme geforderte

245 Bewegung von in ruhenden Flüssigkeiten suspendierten Teilchen, Annalen der Physik 17

246 (8), 549-560 (1905). English translation by A.D. Cowper (1926): Investigations on the

247 theory of Brownian movement.

$248 \quad 30 \quad$ Heath, G. R., Moore, T. C. Jr. \& Dauphin, J. P. Organic Carbon in Deep-Sea Sediments,

249 in The Fate of Fossil Fuel $\mathrm{CO}_{2}$ in the Oceans (eds. Andersen, N. R. \& Malahoff, A.),

$250 \quad$ Plenum Press, New York, 605-625 (1977).

$25131 \quad$ Evans, K.A., The redox budget of subduction zones, Earth-Sci. Rev. 113, 11-32 (2012).

$252 \quad$ Kelley, K. A. and E. Cottrell, Water and the Oxidation State of Subduction Zone

253 Magmas; Science 325 (5940): 605-607 (2009).

$254 \quad 33 \quad$ Laske G. and G.A. Masters, global digital map of sediment thickness. EOS Trans. AGU,

255 78:F483 (1997).

$256 \quad 34 \quad$ Divins D.L., NGDC Total Sediment Thickness of the World's Oceans \& Marginal Seas, $257 \quad$ (NOAA) (2008).

259 Supplementary Information is linked to the online version of the paper at

260 www.nature.com/nature.

261

262 Acknowledgments. This research would not have been possible without the dedicated effort of

263 the drilling crew, ship's crew and scientific staff of the Drillship JOIDES Resolution. We thank

264 Victoria M. Fulfer and Maureen J. Hayden for assistance with data compilation. The project was

265 undertaken as part of Integrated Ocean Drilling Program Expedition (IODP) 329. The expedition

266 was funded by the U.S. National Science Foundation (NSF); the Ministry of Education, Culture, 
267 Sports, Science and Technology, Japan (MEXT); the European Consortium for Ocean Research

268 Drilling; the Ministry of Science and Technology (People's Republic of China); the Korea

269 Institute of Geoscience and Mineral Resources; the Australian Research Council and the New

270 Zealand Institute for Geological and Nuclear Sciences; and the Ministry of Earth Sciences

271 (India). Post-expedition analyses were funded by the NSF through the Center for Dark Energy

272 Biosphere Investigations (C-DEBI), and by the Japan Society for the Promotion and

273 Development (JSPS) Grants-in-Aid for Science Research (no. 26251041, 24651018, 24687004,

274 and GR102 in NEXT Program: to F.I. and Y.M.) through the MEXT. This is C-DEBI publication 275 XXX.

276

277 Author Contributions: S.D. and F.I. led the expedition. C.A.Z. managed the expedition project.

278 S.D., F.I., T.F., R.P. and A.J.S. designed the study. L.J.A., N.D., T.E., H.E., T.F., B.G., R.N.H., 279 B.W.H., J.-H.H., J.K., J.K., J.E.L., S.M., Y.M., R.W.M., R.P., T.S., F.S., C.E.S.-D., D.C.S., 280 A.J.S., B.O.S., Y.S., M.S., L.T., G.U., Y.T.Y, G.Z., X.-H.Z. and W.Z. collected and analysed 281 samples and data. J.S. analysed data. S.D. wrote the manuscript with significant input from F.I., 282 T.F., J.K., R.W.M., Y.M., R.P., J.S. and A.J.S.

284 Author Information: All data are deposited in the IODP database and archived on-line in the 285 IODP Expedition 329 Proceedings. Reprints and permission information are available at 286 www.nature.com/reprints. We report no competing financial interests. Correspondence and 287 requests for materials should be addressed to S.D. (dhondt@mail.uri.edu). 


\section{Figure Legends}

289 Fig 1. Site locations and time-averaged seasurface chlorophyll-a concentrations [Global SeaWiFS Chlorophyll (mean of September 1997 - December 2004)]. Colored dots mark Expedition 329 site locations: U1365 (orange), U1368 (light blue), U1367 (pink), U1368 (green), U1369 (red)), U1370 (dark blue), and U1371 (black). Colored lines mark site

Fig 2. Sedimentary profiles of cell abundance and chemical concentrations ${ }^{7}$, keyed to site paleopositions with tiny dots marking site locations at 20-myr increments. Sites U1365U1370 are located within the SPG oligotrophic region and U1371 is located south of the SPG oligotrophic region. White dots mark drill-sites where life in deep subseafloor sediment has previously been examined.

Fig. 3. Net $\mathrm{O}_{2}$ reaction rates calculated from $\mathrm{O}_{2}$ optode data at SPG Sites U1365, U1366, U1367, location colors in Fig 1: (A) cell concentration (logarithmic scales), (B) dissolved $\mathrm{O}_{2}$, (C) dissolved $\mathrm{NO}_{3}{ }^{-}$, (D) dissolved $\mathrm{PO}_{4}{ }^{-}$, (E) dissolved inorganic carbon, (F) total organic carbon. Profiles span the sediment column, from seafloor to basement. Because optodebased $\mathrm{O}_{2}$ measurements are less noisy than electrode-based measurements, the $\mathrm{O}_{2}$ profiles in (A) are limited to optode data except where sedimentary fabric prevented optode deployment (the lowermost portion of U1367, as well as most of U1368 and $\mathrm{U} 1369$ and $\mathrm{U} 1370$ (SI). Vertical dark blue lines represent mean net $\mathrm{O}_{2}$ reduction rates, U1371). Vertical line in (B) marks the minimum quantification limit (MQL). Open circles in (B) mark data below the MQL. light blue boxes represent the first standard deviation of the mean reaction rate, and vertical lines of open dots with blue margins (ooo) mark intervals where the net $\mathrm{O}_{2}$ reduction rate appears to be negative, but is indistinguishable from zero (SI). The net 
reaction rate is also statistically indistinguishable from zero at sites and depths where the $\mathrm{O}_{2}$ reduction rate is positive and the light blue boxes intersect the left side of the panel (at these depths the first standard deviation of the rate overlaps with zero). Dissolved $\mathrm{O}_{2}$ is present throughout the sediment column at all six SPG sites. We did not calculate reaction rates for intervals that lack optode data (the lowermost sediment of U1367 and all of U1368) and intervals disturbed by drilling (cross-hatched intervals). Basaltic

318 Fig 4. Regions where we predict dissolved $\mathrm{O}_{2}$ and aerobic activity to persist from seafloor to igneous basement, based on mean sediment accumulation rates and mean sediment thicknesses (SI). Red dots indicate coring sites where dissolved $\mathrm{O}_{2}$ diffusively penetrates the entire sediment column (up to $75 \mathrm{mbsf})^{5,7,20}$. At these sites, sediment thickness was determined by drilling or piston-coring the entire sediment column. Black dots indicate sites where dissolved $\mathrm{O}_{2}$ disappears in $\mathrm{cm}$ to meters below the seafloor ${ }^{6,12}$. Yellow dots indicate sites where dissolved $\mathrm{O}_{2}$ penetrates more than 7 to $34 \mathrm{mbsf}$ and may penetrate to basement but $\mathrm{O}_{2}$ content is not fully characterized throughout the entire sediment column ${ }^{5,6,8,20}$. The dark blue area represents the minimum area over which dissolved $\mathrm{O}_{2}$ permeates the entire sediment sequence and the upper basement; it is defined by combinations of mean sediment thicknesses from standard global maps ${ }^{33,34}$ (averaged over five-minute grids) and mean sediment accumulation rates comparable to the singlesite sediment thicknesses and sedimentation rates where $\mathrm{O}_{2}$ is known from direct measurements to penetrate the entire sediment sequence. Some sites where $\mathrm{O}_{2}$ is known to penetrate the entire sediment column are outside this region; this discrepancy results from regionally interpolated estimates of mean sediment thickness ${ }^{33,34}$ being greater than 
334 the sites' local sediment thicknesses determined by drilling to basement. The light blue area represents the maximum area over which dissolved $\mathrm{O}_{2}$ permeates the entire sediment

336 sequence from the overlying seafloor; it is defined by combinations where (i) dissolved

337 chemical data indicate that $\mathrm{O}_{2}$ may penetrate the entire column but chemical data 338 resolution is too low to be certain or (ii) $\mathrm{O}_{2}$ penetrates the entire sediment column at 339 individual sites, but the regionally interpolated estimate of mean sediment thickness is 340 greater than direct measurements of sediment thickness at the drilled sites. Dissolved $\mathrm{O}_{2}$ 341 may be present in the igneous basement over an even greater area, due to seawater 342 advection through the basement. 
344 Fig 1.

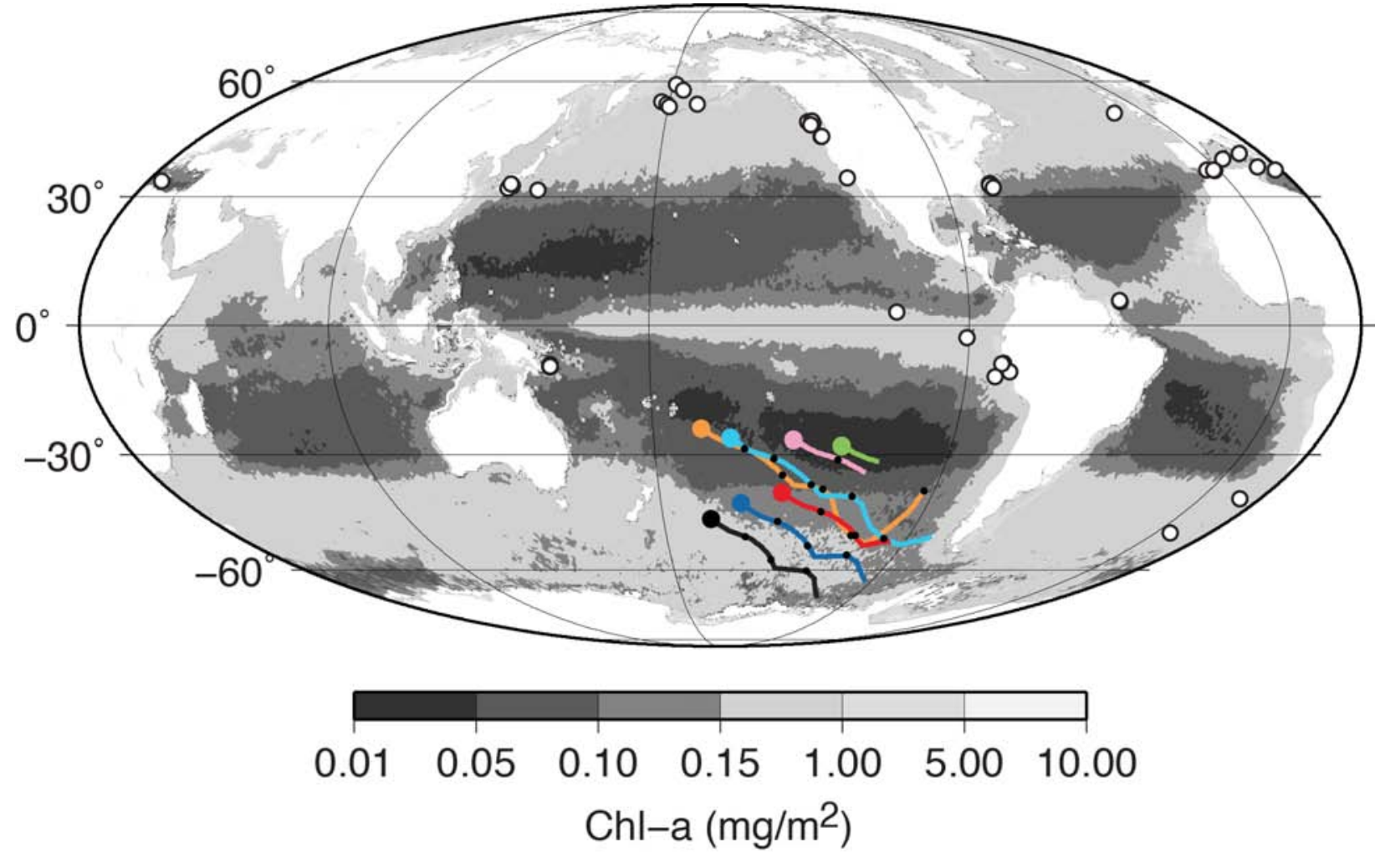

345

346 
Fig 2.

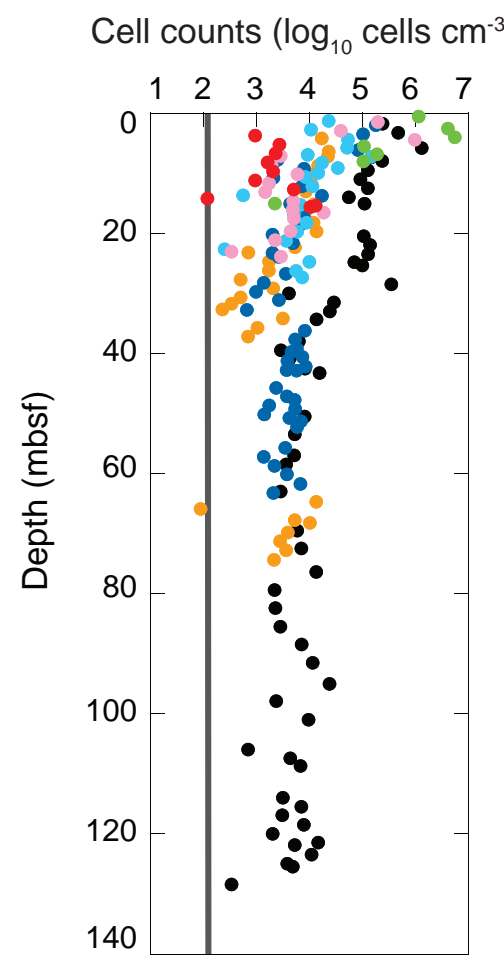

Oxygen $(\mu \mathrm{M})$
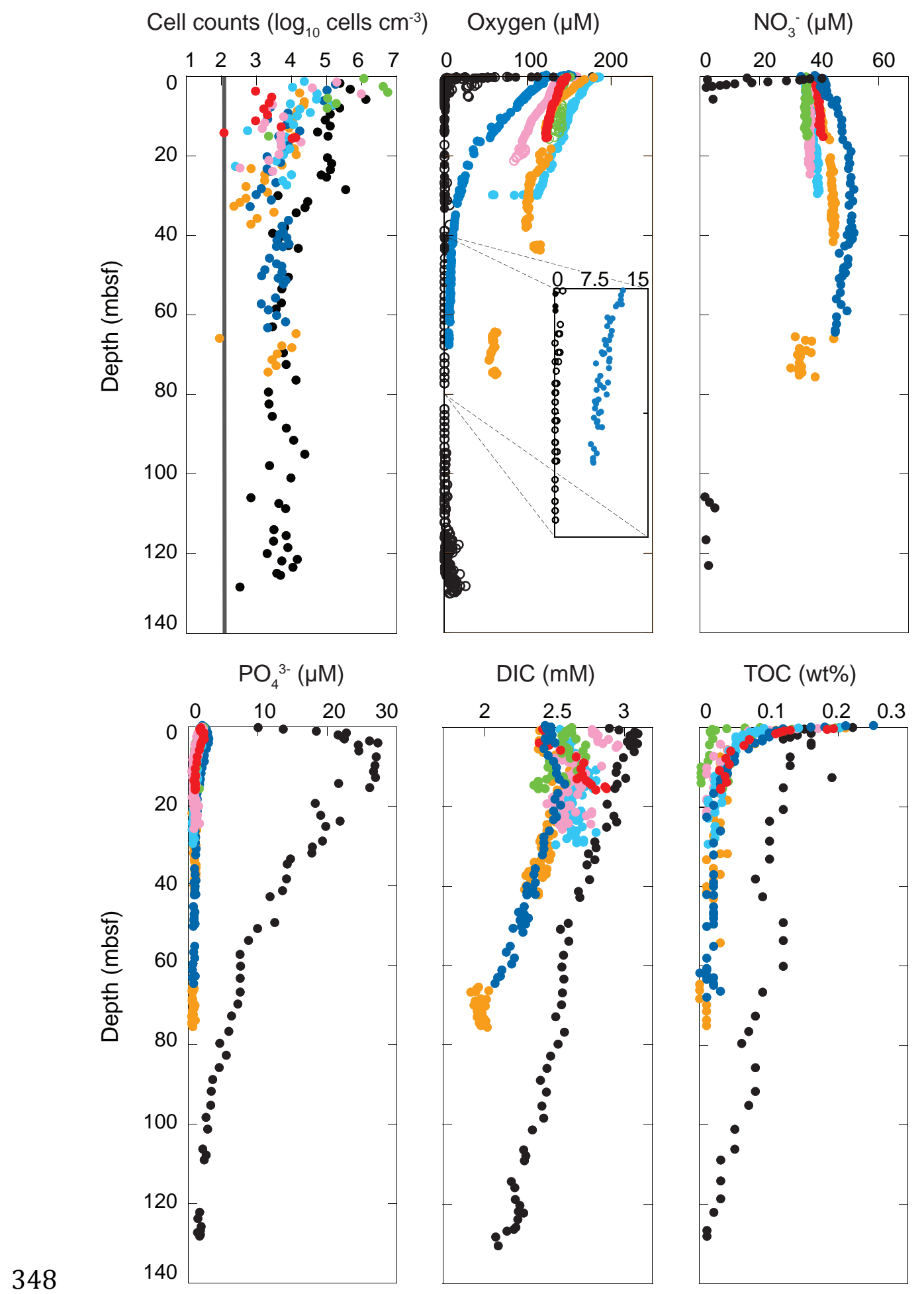
$351 \quad$ Fig 3.

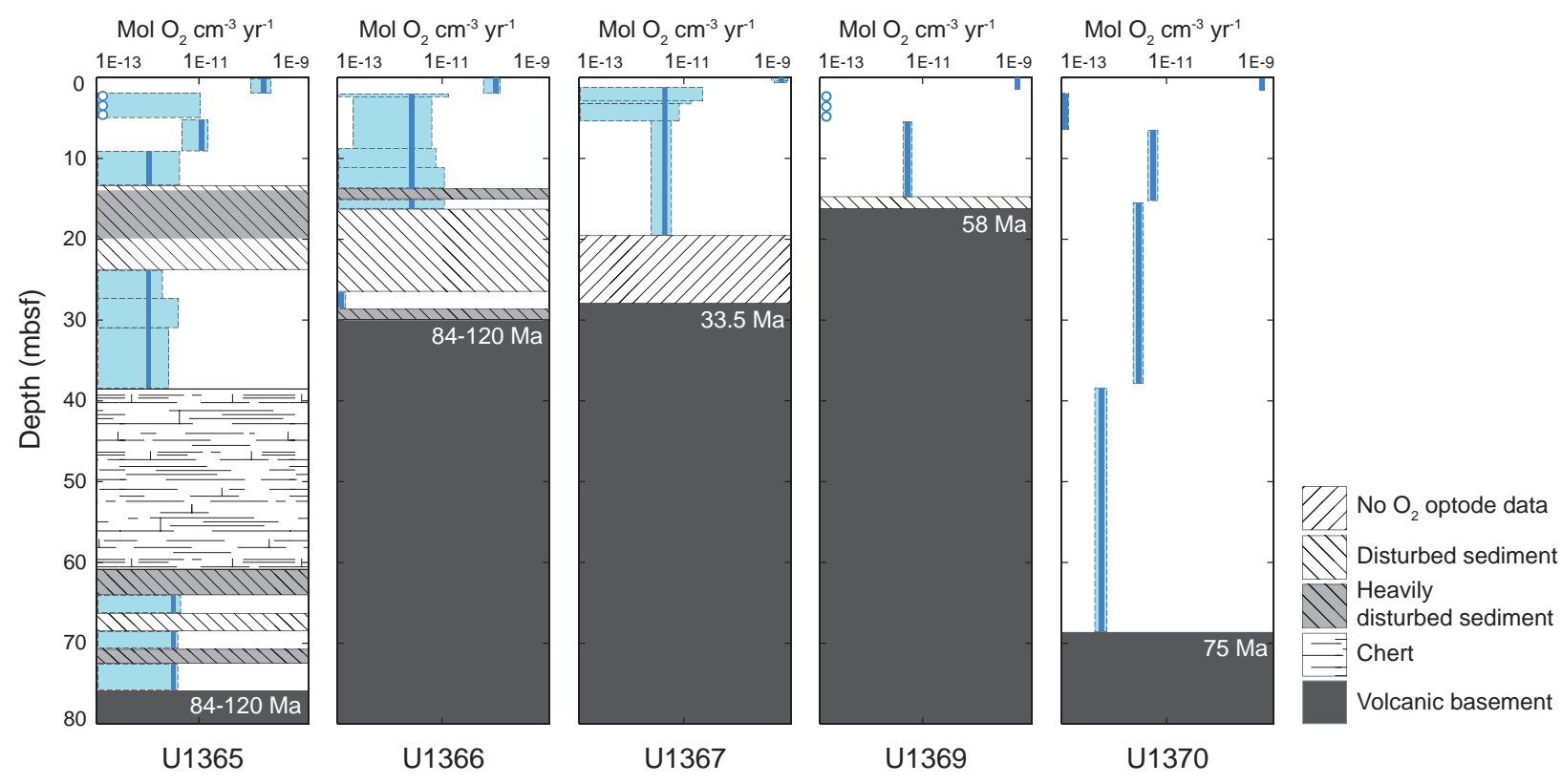

353 
$354 \quad$ Fig 4.

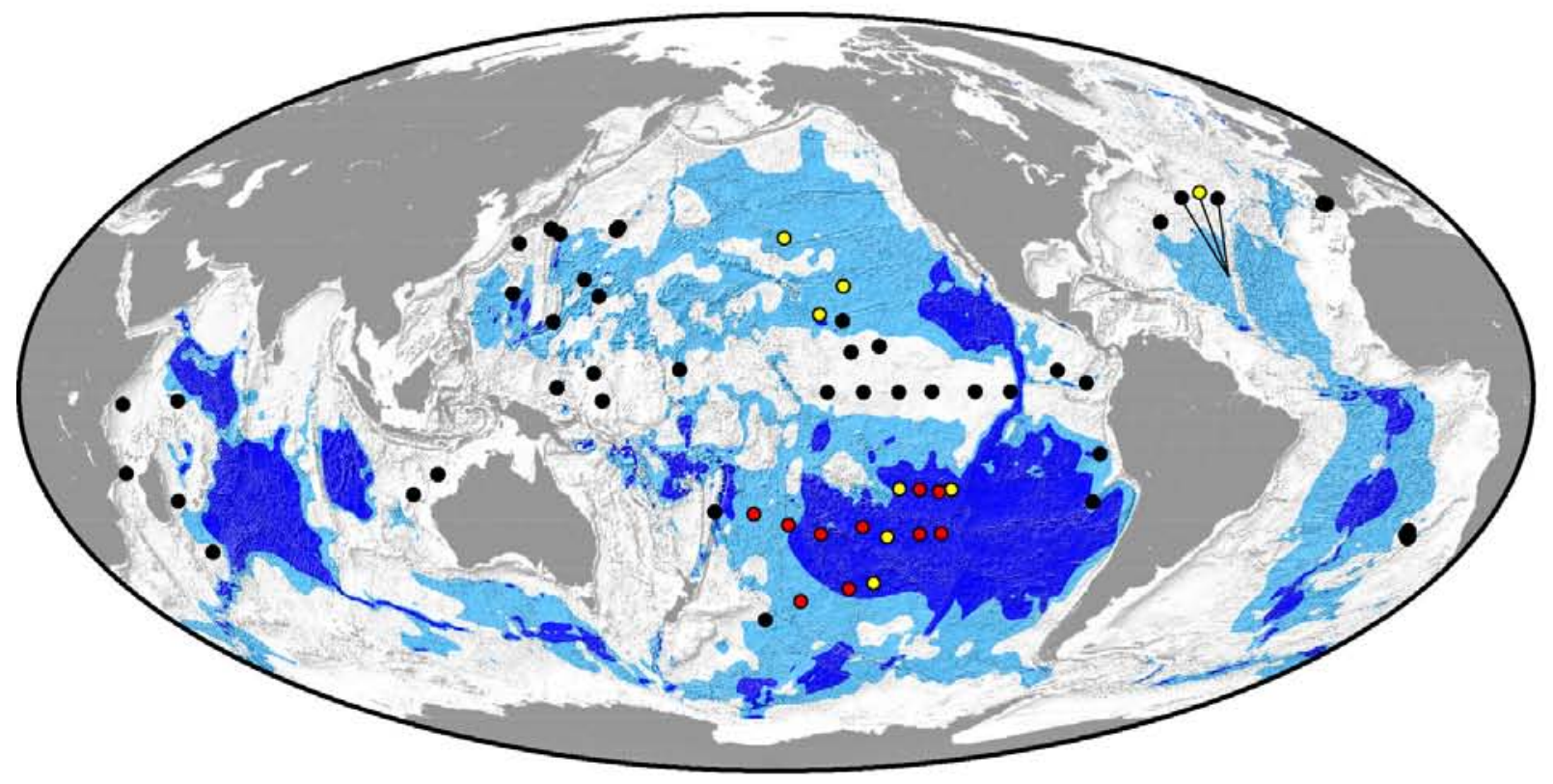

355 


\section{Supplementary Information}

\section{Chemical, physical and geological data}

$4 \quad$ All Expedition 329 chemical, physical and geological data and their measurement

5 protocols are described in reference 1 . We present site details and summary results in

6 Table 1. All samples were taken by piston coring in advance of the drill bit ${ }^{1}$.

\section{Cell enumeration procedures}

9 We provide the cell-count data for this manuscript in Table 2. These are not the

10 shipboard data in reference 1; the minimum quantification limit (MQL) for the shipboard

11 cell counts $\left(\sim 10^{3} \text { cells } / \mathrm{cm}^{3}\right)^{1}$ was too high to conclusively test the presence or absence of

12 microbial cells in the deepest, oldest sediment of our sites. Consequently, we greatly

13 refined the cell-counting protocols and undertook new counts for this manuscript after the 14 expedition.

15 For cell enumeration, we routinely took $2-\mathrm{cm}^{3}$ samples from the center of cut core 16 ends using a $3-\mathrm{cm}^{3}$ syringe. Each $2-\mathrm{cm}^{3}$ sediment plug was extruded into a sterile $15-\mathrm{ml}$

17 centrifuge tube containing $8 \mathrm{ml}$ of $2.5 \%(\mathrm{w} / \mathrm{v}) \mathrm{NaCl}$ solution with $2 \%(\mathrm{v} / \mathrm{v})$ formalin as a

18 fixative, and then thoroughly shaken to form a homogenous suspension. We performed

19 cell counts by a fluorescence color-based cell enumeration technique using SYBR Green

20 I fluorescent dye ${ }^{2}$. To evaluate low-density populations (below $10^{4} \mathrm{cells}^{-3)}$, we

21 detached cells from sediment by using a multi-layer density gradient technique ${ }^{3}$. For 
22 blank samples, we replaced the sediment slurry with sterile-filtered TE Buffer. We then

23 counted cell numbers by either manual or computer-based microscopic observations ${ }^{2,4}$.

24 We defined the MQL as the mean of the blank counts plus three times their standard

25 deviation. As shown in manuscript Fig 2, the MQL for these counts is 130 cells $/ \mathrm{cm}^{3}$. We

26 carried out all filter preparation steps, including sonication of sediment and SYBR Green

27 I staining, in an ultra-clean bench placed in a HEPA-filtered clean booth at the Kochi

28 Institute for Core Sample Research, JAMSTEC.

29 We confirmed the presence of dissolved $\mathrm{O}_{2}$ throughout the sediment column at all six

30 SPG sites by independently undertaking parallel $\mathrm{O}_{2}$ measurements for each site using

31 fiber-optic $\mathrm{O}_{2}$ microsensors (optodes) ${ }^{5}$ and amperometric Clark-type $\mathrm{O}_{2}$ sensors

32 (microelectrodes) ${ }^{6}$. For consistency, we used optode data for all $\mathrm{O}_{2}$ calculations and

33 illustration, except for Sites U1368 and U1371, where optode data are limited to small

34 fractions of the sediment column; at those sites, electrode-based measurements are used

35 for illustration.

\section{Calculation of $\mathrm{O}_{2}$ exposure times}

38 We calculated $\mathrm{O}_{2}$ exposure times ${ }^{7}$ by dividing $\mathrm{O}_{2}$ penetration depth by sediment age

39 at the depth of $\mathrm{O}_{2}$ penetration. For Sites U1365 to U1370, $\mathrm{O}_{2}$ penetration depth equals

40 total sediment thickness and sediment age at the depth of $\mathrm{O}_{2}$ penetration equals basement

41 age $^{1}$. For Site U1371, we used mean sediment accumulation rate calculated from

42 sediment thickness and basement age to estimate sediment age at depth of $\mathrm{O}_{2}$ penetration.

43

\section{Comparison of dissolved $\mathrm{O}_{2}$ to dissolved $\mathrm{NO}_{3}^{-}$}


45 Because $\mathrm{O}_{2}$ measurements and $\mathrm{NO}_{3}{ }^{-}$measurements were made at different sediment

46 depths and (often) in different holes, we interpolated $\mathrm{O}_{2}$ concentrations for comparison to

$47 \mathrm{NO}_{3}{ }^{-}$in SI Fig 1. Because the diffusion coefficient of dissolved $\mathrm{O}_{2}$ is about $10 \%$ higher

48 than that of $\mathrm{NO}_{3}{ }^{-}$at in situ temperatures ${ }^{8}, \mathrm{O}_{2}$ diffuses into the sediment slightly faster

49 than $\mathrm{NO}_{3}{ }^{-}$diffuses out. This difference is consistent with the slight excess of $\mathrm{NO}_{3}{ }^{-}$

50 relative to the Redfield $\mathrm{O}_{2} / \mathrm{NO}_{3}{ }^{-}$respiration ratio in at the sites with greatest sediment

51 thickness (U1365 and U1370). To account for the slight difference in diffusion

52 coefficients of $\mathrm{O}_{2}$ and $\mathrm{NO}_{3}{ }^{-}$, the relationship of $\mathrm{O}_{2}$ and $\mathrm{NO}_{3}{ }^{-}$profiles to the Redfield ratio

53 in subseafloor SPG sediment has been quantitatively tested by use of a diffusion-reaction

54 model for the $\mathrm{O}_{2}$ and $\mathrm{NO}_{3}{ }^{-}$data of Site $\mathrm{U} 1370^{9}$; this test demonstrated that the best-fit NO

$55{ }_{3}^{-} /-\mathrm{O}_{2}$ respiration ratio is indistinguishable from the Redfield ratio throughout the

56 sediment column.

57

\section{Reaction rate calculations}

59 We quantified vertical distributions of $\mathrm{O}_{2}$ reaction (aerobic respiration) rates (Table

60 3) using the MatLab program and numerical procedures of reference 10, with dissolved

$61 \mathrm{O}_{2}$ concentrations, physical properties (in situ temperature, porosity, formation factor)

62 and sediment burial rates from reference 1. For our calculations, we assumed fluid

63 advection rates to be below detection. We derived our diffusion coefficients from in situ

64 temperature data ${ }^{1}$ and diffusion coefficients of $\mathrm{O}_{2}$ in seawater at standard temperatures ${ }^{8}$.

65 The algorithm for calculating reaction rates uses iterative numerical procedures to

66 identify the maximum number of depth intervals with statistically different reaction rates

67 at a prescribed significance level $(\alpha=0.05)$. It explicitly accounts for downhole variation 
68 in physical properties and measurement spacing.

69 A key variable in this approach is the user-defined minimum number of data points 70 required to define a reaction zone. We used a minimum of either 5 data points (for Sites

71 U1365, U1367, U1369, U1370)) or 7 data points (for Site U1366) to define the minimum

72 reaction zones for our calculations after testing a range of values from 3-21 data points.

73 Our selection of these minimum reaction zones was based on the fit of an algorithm-

74 derived best-fit line to the actual $\mathrm{O}_{2}$ measurements and the complexity or variability of

75 the defined reaction rate zones. For example, reaction zones defined by fewer than 5

76 points exhibited nice fits to the actual $\mathrm{O}_{2}$ data, but the resulting reactions rates were very

77 erratic and unrealistic as the values often alternated rapidly between positive and negative

78 values. This erratic character resulted from rapid changes in slope of the best-fit line used

79 to derive reaction rates. For reaction zones defined by more than 7 points, the best-fit line

80 departed significantly from the actual $\mathrm{O}_{2}$ measurements, and the reaction zones are

81 typically too broad and underestimated the characteristic reaction rate. Our selection of

82 the 5- or 7-point minimum reaction zone iteration depended on which number of points

83 per minimum zone yielded a lower uncertainty.

84 We used a Monte Carlo technique to estimate uncertainties in the calculated reaction

85 rates $^{10}$. The key variables for the uncertainty estimate are the precision of the $\mathrm{O}_{2}$

86 measurement and the number of reaction rate iterations. For our results, we used a $1 \%$

87 measurement precision with 50 iterations.

88 At Sites U1365, U1369 and U1370, the program calculated brief intervals of net $\mathrm{O}_{2}$

89 production for the second reaction zone below the seafloor. These results are essentially

90 indistinguishable from zero (see Table 3 and manuscript Fig 3 ) and disappear if we 
91 calculate the mean rates over longer data intervals. Their cause is unclear, but their

92 consistent occurrence in the second reaction interval at each site suggests that they may

93 be an artifact of the rapid change in $\mathrm{O}_{2}$ gradient at this depth and the very small number

94 of data points in this reaction subzone (five).

95 We calculated per-cell respiration rates from these reaction rates and the cell counts

96 in manuscript Fig 2a. These rates were converted to electron transport rates assuming

97 transfer of 4 electrons per $\mathrm{O}_{2}$ molecule reduced. We calculated per-cell respiration rates

98 for equatorial Pacific ODP Site 1226 using sulfate reduction rates from reference 10, cell

99 counts from reference 11, and assuming transfer of 8 electrons via reduction of each

100 sulfate ion.

101

102 Predicting the global distribution of $\mathbf{O}_{2}$ and aerobic communities from seafloor to

103 basement

104 To map where oxygen may be present in the sediment from seafloor to basement, we

105 examined the relationship between $\mathrm{O}_{2}$ penetration to basement and several relevant

106 variables for which there are globally extrapolated maps; these variables included

107 estimates of mean annual seasurface chlorophyll content ${ }^{12}$, particulate organic carbon

108 flux at $2 \mathrm{~km}$ waterdepth ${ }^{13}$, seafloor carbon deposition flux ${ }^{14}$, organic carbon burial rate ${ }^{15}$,

$109{ }^{16}$, seafloor oxygen flux ${ }^{15,16}$, oxygen-equivalent carbon flux ${ }^{16}$, sediment thickness ${ }^{17,18}$,

110 and mean sedimentation rate (calculated as described below). Global extrapolations of

111 seafloor carbon deposition flux, seafloor oxygen flux and sedimentation rate are generally

112 correlated because seafloor carbon deposition flux and seafloor oxygen flux are typically

113 calculated from estimates of sedimentation rate e.g., $15,16^{.}$ 
114 Of these variables, we found the combination of mean sediment accumulation rates

115 and sediment thickness best explained the distribution of sites where dissolved $\mathrm{O}_{2}$ does or

116 does not penetrate from seafloor to basement. Consequently, we used sediment thickness

117 and mean sediment accumulation rates to create a map that predicts where oxygen is

118 likely to be present throughout the entire sediment column. We created the global

119 sediment accumulation rate map by merging sediment thickness grids ${ }^{17,18}$ and dividing

120 by the basement age grid $^{19}$. For these maps, we resampled the original grids ${ }^{17-19}$ at a 5-

121 minute grid interval. We used Generic Mapping Tools software ${ }^{20}$ for grid manipulations

122 and calculations.

123 To define combinations of sediment thickness and sediment accumulation rate for

124 regions with oxic sediment to basement, we used dissolved $\mathrm{O}_{2}$ measurements ${ }^{1,21-23}$ or

125 measurements of dissolved $\mathrm{NO}_{3}{ }^{-}$concentrations that approximate or exceed local bottom-

126 water values ${ }^{24}$. At sites where dissolved $\mathrm{O}_{2}$ measurements approach zero ${ }^{23}$, we detrended

127 the data, discarded measurements that lie outside the second standard deviation of the

128 data profile and then determined if zero fell within the second standard deviation of the

129 remaining measurements. To define combinations of sediment thickness and sediment

130 accumulation rate for regions with anoxic sediment at depth, we used profiles of

131 dissolved $\mathrm{O}_{2}, \mathrm{NO}_{3}{ }^{-}$, dissolved manganese, dissolved iron, dissolved $\mathrm{SO}_{4}{ }^{2-}$ and dissolved

$132 \mathrm{CH}_{4}$ from Deep Sea Drilling Project, Ocean Drilling Program and Integrated Ocean

133 Drilling Program sites ${ }^{25}$ and profiles of dissolved $\mathrm{O}_{2}$ from deep piston coring sites ${ }^{21,22}$.

134 We examined dissolved chemical profiles from 401 open-ocean DSDP, ODP and IODP

135 drill sites and 24 long-coring sites that geographically bound the regions of possible $\mathrm{O}_{2}$

136 penetration to basement (425 total sites). To previent our results from being affected by 
137 small numbers of bad measurements at individual sites, we limited this analysis to the

138149 sites (of the 425) that exhibit smoothly varying concentration profiles for

139 measurements of one or more of these dissolved chemicals. At eight sites, we used

140 dissolved manganese as evidence of $\mathrm{O}_{2}$ absence, following the standard assumptions that

141 (i) manganese is not reduced in oxic environments ${ }^{26,8}$ and (ii) dissolved manganese is

142 predominantly reduced $\left[\mathrm{Mn}(\mathrm{II})\right.$ and $\mathrm{MnCl}^{+} 27$ or ligand-stabilized $\left.\mathrm{Mn}(\mathrm{III})^{28}\right]$. However,

143 recent studies have recorded dissolved manganese concentrations of a few micromolar in

144 subseafloor sediment with abundant dissolved $\mathrm{O}_{2}$ in the South Pacific Gyre ${ }^{1}$ and the

145 North Pacific Gyre (R.W. Murray, pers. comm. 8/14); whether these concentrations are

146 sampling artifacts or (meta)stable concentrations of dissolved manganese in strongly oxic

147 sediment remains to be determined.

\section{Assessment of influence on subducting sediment}

150 To assess effects of $\mathrm{O}_{2}$ penetration depth on the chemistry of subducting sediment, we

151 examined published records of sediment composition at DSDP/ODP/IODP sites seaward

152 of subduction zones. In some regions, sediment sequences that we infer to be fully

153 penetrated by $\mathrm{O}_{2}$ directly enter a subduction zone (e.g., the Tonga Trench and the central

154 and southern portions of the Peru-Chile Trench) (see manuscript Fig 4). In other regions,

155 sedimentation rate and sediment thickness increase as the trench is approached. Despite

156 anoxia in the upper sediment column of the latter regions, a great deal of oxidized

157 material is present deeper in the sediment. For example, porewater chemical profiles

158 indicate that manganese reduction is dominant in the upper sedimentary column of DSDP

159 Site Sites 1149 and 1231, which respectively approach the Izu-Bonin Trench and the 
160 northern Peru-Chile Trench ${ }^{29,11}$. In such sequences, dissolved $\mathrm{O}_{2}$ is not present in the

161 upper sediment column at the time of subduction, but oxidized iron and oxidized

162 manganese may remain abundant in solid phases at greater depth (e.g., DSDP Sites 303,

$163426,578$ and 581$)^{30-32}$ and dissolved $\mathrm{O}_{2}$ and $\mathrm{NO}_{3}{ }^{-}$may be present in the deepest sediment

164 and the upper basement ${ }^{11}$.

165

166

References

1671 D'Hondt, S., Inagaki, F., Alvarez Zarikian, C.A., \& the Expedition 329 Scientists,

168 Proc. IODP 329: Tokyo (Integrated Ocean Drilling Program Management

169 International, Inc.) (2011).

1702 Morono, Y., Terada, T., Masui, N. \& Inagaki, F. Discriminative detection and

171 enumeration of microbial life in marine subsurface sediments. ISME Journal $\mathbf{3}$,

$172 \quad 503-511(2009)$.

173 3. Morono, Y., T. Terada, J. Kallmeyer and F. Inagaki, An improved cell separation

174 technique for marine subsurface sediments: applications for high-throughput

175 analysis using flow cytometry and cell sorting, Environ. Microbiol. 15, 2841-2849

$176 \quad$ (2013).

1774 Morono, Y. \& Inagaki, F. Automatic Slide-Loarder Fluorescence Microscope for

178 Discriminative Enumeration of Subseafloor Life. Scientific Drilling 9, 32-36

$179 \quad$ (2010).

1805 Fischer, J. P., Ferdelman, T.G., D'Hondt, S., Røy, H. \& Wenzhöfer, F. Oxygen

181 penetration deep into the sediment of the South Pacific gyre. Biogeosciences 6,

$182 \quad 1467-1478(2009)$. 
1836 Revsbech, N.P. An oxygen microsensor with a guard cathode. Limnol. Oceanogr.

$184 \quad 34,474-478(1989)$.

1857 Hartnett, H.E., R.G. Keil, J.I. Hedges and A.H. Devol, Influence of oxygen

186 exposure time on the preservation of organic carbon in continental margin

187 sediments, Nature 391 572-574 (1998).

1888 Schulz, H.D. in Marine Geochemistry, H. D. Schulz, M. Zabel, Eds. (Springer-

189 Verlag, Heidelberg, New York, 2000), 85-128.

1909 Huang, $\mathrm{Y} .$, "The $\mathrm{NO}_{3}{ }^{-} / \mathrm{O}_{2}$ respiration ratio of the deep sedimentary biosphere in

191 the Pacific gyres" (2014). Dissertations and Master's Theses (Campus Access).

192 Paper AAI1555654. http://digitalcommons.uri.edu/dissertations/AAI1555654.

19310 Wang, G., A.J. Spivack, S. Rutherford, U. Manor and S. D'Hondt, Quantification

194 of co-occurring reaction rates in deep subseafloor sediments, Geochim.

195 Cosmochim. Ac. 72, 3479-3488 (2008).

19611 D'Hondt, S., and 34 others, Distributions of microbial activities in deep

197 subseafloor sediments, Science 306, 2216-2221.

$198 \quad 12 \quad$ Global SeaWiFS Chlorophyll (mean of September 1997 - December 2004

19913 Henson, S.A., R. Sanders and E Madsen, Global patterns in efficiency of

200 particulate organic carbon export and transfer to the deep ocean, Global

201 Biogeochemical Cycles 26, GB1028 (2012).

20214 Dunne, J. P., J.L. Sarmiento, and A. Gnanadesikan, A synthesis of global particle

203 export from the surface ocean and cycling through the ocean interior and on the

204 seafloor, Global Biogeochem. Cycles 20 (2007). 
20515 Jahnke, R.A. and G.A. Jackson, The spatial distribution of sea floor oxygen

206 consumption in the Atlantic and Pacific Oceans, in Rowe, G.T., and Parient, V.,

207 eds., Deep-Sea Food Chains and the Global Carbon Cycle, p. 295-307 (1992).

20816 Jahnke, R. A. The global ocean flux of particulate organic carbon: areal

209 distribution and magnitude. Global Biogeochem. Cycles 10, 71-88 (1996).

21017 Divins D.L. NGDC Total Sediment Thickness of the World's Oceans \& Marginal

211 Seas (NOAA) (2008).

21218 Laske, G. and G.A. Masters, global digital map of sediment thickness. EOS

213 Trans. $A G U$ 78, F483 (1997).

21419 Müller R. D., Sdrolias M., Gaina C., \& Roest W. R. Age, spreading rates, and 215 spreading asymmetry of the world's ocean crust. Geochem. Geophys. Geosy. 9

$216 \quad$ (2008).

$21720 \quad$ Wessel P. \& Smith W.H.F. New, inproved version of the Generic Mapping Tools

218 released. EOS Trans. AGU. 79, 579 (1998).

21921 D'Hondt, S. et al. Subseafloor sedimentary life in the South Pacific Gyre. Proc.

220 Nat. Acad. Sci. U.S.A. 106, 11651-11656 (2009).

22122 Røy, H., J. Kallmeyer, R.R. Adhikari, R. Pockalny, B.B Jørgensen and S.

222 D'Hondt, Aerobic microbial respiration in 86-million-year-old deep-sea red clay,

223 Science 336 (6083), 922-925 (2012). Erratum (figure correction) in Science 336

224 (6088), $1506(2012)$.

22523 Orcutt, B.N., et al., Oxygen consumption rates in subseafloor basaltic crust

226 derived from a reaction transport model, Nat. Commum. 4, 2539 (2013). 
$227 \quad$ Gieskes, J.M. and J. Boulegue, Interstitial Water Studies, Leg-92, Init. Rep. DSDP

$228 \quad 92,423-429(1986)$.

22925 DSDP/ODP/IODP Core database. College Station, TX: International Ocean

230 Discovery Program. <http://iodp.tamu.edu/database/index.html>

$23126 \quad$ Froelich, P. N., Klinkhammer, G. P., Bender, M. L., Luedtke, N. A., Heath, G. R.,

232 Cullen, D., Dauphin, P., Hammond, D., Hartman, B., \& Maynard. V. Early

233 oxidation of organic matter in pelagic sediments of the eastern equatorial Atlantic:

234 suboxic diagenesis, Geochim. Cosmochim. Ac. 43, 1075-1090 (1979).

23527 Bruland, K. Trace elements in seawater, in Chemical Oceanography, 2nd Edition,

236 Vol. 8 (ed. Riley, J. P., \& Chester, R.), Academic, London, 147-220 (1983).

23728 Madison, A. S., Tebo, B. M., Mucci, A., Sundby, B. \& Luther, G. W. III,

238 Abundant porewater $\mathrm{Mn}(\mathrm{III})$ is a major component of the sedimentary redox

239 system, Science 341, 875-878 (2013).

24029 Shipboard Scientific Party, 2000. Site 1149. In Plank, T., Ludden, J.N., Escutia,

241 C., et al., Proc. ODP, Init. Repts., 185 [Online]. Available from World Wide

242 Web: <http://www-odp.tamu.edu/publications/185_IR/chap_03/chap_03.htm>.

$243 \quad 30 \quad$ Larson, R.L., and 9 others, Site 303: Japanese Magnetic Lineations, in R.L.

244 Larson, R. Moberly et al., Initial Reports DSDP 32, Washington D.C. (U.S.

245 Government Printing Office) (1975).

24631 Shipboard Scientific Party, with P.S. Doyle, 5. Site 578, in G.R. Heath, L.H.

247 Burckle et al., Initial Reports DSDP 86, Washington D.C. (U.S. Government

248 Printing Office) (1985). 
$24932 \quad$ Heath, G.R., R.B. Kovar and C. Lopez, Geochemistry of Sediments at Sites 579, 250 580, and 581, Deep Sea Drilling Project Leg 86, Western North Pacific, in G.R.

251 Heath, L.H. Burckle et al., Initial Reports DSDP 86, Washington D.C. (U.S.

252 Government Printing Office) (1985).

$253 \quad 33$ Anderson, L.A. and J.L. Sarmiento, Global ocean phosphate and oxygen

254 simulations. Glob. Biogeochem. Cy. 9, 621-636 (1995).

255

256 
257 Table 1. Site properties ${ }^{1}$ and depth-integrated $\mathrm{O}_{2}$ reduction rates below 1.5 mbsf. n.d. $=$ 258 not determinable (no optode data). n.a. = not applicable $\left(\mathrm{O}_{2}\right.$ does not penetrate to $259 \quad 1.5 \mathrm{mbsf}$ at U1371).

260

\begin{tabular}{|c|c|c|c|c|c|c|c|}
\hline Site & Latitude & Longitude & $\begin{array}{c}\text { Water } \\
\text { depth } \\
\text { (m) }\end{array}$ & 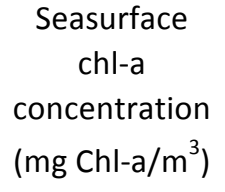 & $\begin{array}{l}\text { Total } \\
\text { sediment } \\
\text { thickness } \\
\text { (m) }\end{array}$ & $\begin{array}{c}\mathrm{O}_{2} \\
\text { exposure } \\
\text { time } \\
\text { (Ma) }\end{array}$ & $\begin{array}{c}\mathrm{O}_{2} \text { consumption } \\
\text { in sediment } \\
>1.5 \mathrm{mbsf} \\
\left(\mathrm{mol} / \mathrm{cm}^{2} / \mathrm{yr}\right)\end{array}$ \\
\hline \multicolumn{8}{|c|}{ Within gyre } \\
\hline U1365 & $-23^{\circ} 51^{\prime}$ & $-165^{\circ} 39^{\prime}$ & 5695 & 0.057 & 75 & $84-120$ & $-2.20 \mathrm{E}-08$ \\
\hline U1366 & $-26^{\circ} 03^{\prime}$ & $-156^{\circ} 54^{\prime}$ & 5127 & 0.054 & 30 & $84-120$ & $-6.28 \mathrm{E}-09$ \\
\hline U1367 & $-26^{\circ} 29^{\prime}$ & $-137^{\circ} 56^{\prime}$ & 4289 & 0.035 & 27 & 33.5 & $-2.03 E-09$ \\
\hline U1368 & $-27^{\circ} 55^{\prime}$ & $-123^{\circ} 10^{\prime}$ & 3740 & 0.030 & 16 & 13.5 & n.d. \\
\hline U1369 & $-39^{\circ} 19^{\prime}$ & $-139^{\circ} 48^{\prime}$ & 5277 & 0.110 & 16 & 58 & $-3.24 \mathrm{E}-09$ \\
\hline U1370 & $-41^{\circ} 51^{\prime}$ & $-153^{\circ} 06^{\prime}$ & 5075 & 0.138 & 68 & 75 & $-1.77 \mathrm{E}-08$ \\
\hline \multicolumn{8}{|c|}{ Outside gyre } \\
\hline U1371 & $-45^{\circ} 58^{\prime}$ & $-163^{\circ} 11^{\prime}$ & 5305 & 0.199 & 131 & 0.035 & n.a. \\
\hline
\end{tabular}


263 Table 2. Post-expedition cell counts for Expedition 329 sites. The cell counts shown in

264 manuscript Fig 2a and used for our per-cell reaction rate calculations (Table 3)

265 were limited to counts from sedimentary intervals described by shipboard

266 scientists as characterized by no visible sediment disturbance or only slight

267 disturbance ${ }^{1}$. Counts from sediment described by shipboard scientists ${ }^{1}$ as heavily

268 disturbed, moderately disturbed or affected by flow-in were excluded from

269 manuscript Fig 2a and our per-cell calculations. Define disturbance notes of

270 fourth column. The extent of sediment disturbance at each sampling depth is

271 identified in the Disturbance intensity column as follows: H (heavily disturbed),

272 M (moderately disturbed, S (slightly disturbed), F (flow-in). Intervals free of

273 visible disturbance are left blank in the Disturbance intensity column.

\begin{tabular}{|c|c|c|c|c|c|c|c|}
\hline Site & Hole & core & section & $\mathrm{cm}$ interval & $\begin{array}{l}\text { Depth } \\
\text { (mbsf) }\end{array}$ & $\begin{array}{l}\text { Cell abundance } \\
\text { (cells } / \mathrm{cm}^{3} \text { ) }\end{array}$ & $\begin{array}{c}\text { Disturbance } \\
\text { intensity }\end{array}$ \\
\hline U1365 & B & 1 & 1 & $40-50$ & 0.5 & $5.14 \times 10^{5}$ & $\mathrm{H}$ \\
\hline U1365 & B & 1 & 2 & $40-50$ & 2.0 & $5.29 \times 10^{4}$ & $M$ \\
\hline U1365 & $B$ & 1 & 3 & $40-50$ & 3.5 & $3.02 \times 10^{4}$ & $M$ \\
\hline U1365 & B & 2 & 1 & $75-85$ & 4.9 & $1.69 \times 10^{4}$ & \\
\hline U1365 & $B$ & 2 & 2 & $140-150$ & 7.1 & $2.27 \times 10^{4}$ & \\
\hline U1365 & B & 2 & 3 & 75-85 & 7.9 & $2.19 \times 10^{4}$ & \\
\hline U1365 & B & 2 & 4 & $75-85$ & 9.4 & $1.44 \times 10^{4}$ & \\
\hline U1365 & $B$ & 2 & 5 & $75-85$ & 10.9 & $1.00 \times 10^{4}$ & \\
\hline U1365 & B & 2 & 6 & $75-85$ & 12.4 & $1.06 \times 10^{4}$ & \\
\hline U1365 & $B$ & 2 & 7 & $58-68$ & 13.7 & $8.41 \times 10^{3}$ & \\
\hline U1365 & $B$ & 3 & 1 & $75-85$ & 14.4 & $1.31 \times 10^{4}$ & $S$ \\
\hline U1365 & B & 3 & 2 & $75-85$ & 15.9 & $1.18 \times 10^{4}$ & \\
\hline U1365 & $B$ & 3 & 3 & $75-85$ & 17.4 & $8.00 \times 10^{3}$ & \\
\hline U1365 & B & 3 & 4 & $75-85$ & 18.9 & $1.17 \times 10^{4}$ & \\
\hline U1365 & B & 3 & 5 & $75-85$ & 20.4 & $1.33 \times 10^{4}$ & \\
\hline U1365 & $B$ & 3 & 6 & $75-85$ & 21.9 & $4.43 \times 10^{3}$ & \\
\hline U1365 & $B$ & 3 & 7 & $40-50$ & 23.1 & $5.22 \times 10^{3}$ & \\
\hline
\end{tabular}




\begin{tabular}{|c|c|c|c|c|c|c|c|}
\hline U1365 & B & 4 & 1 & $75-85$ & 23.9 & $6.91 \times 10^{2}$ & \\
\hline U1365 & B & 4 & 2 & $75-85$ & 25.4 & $1.71 \times 10^{3}$ & \\
\hline U1365 & B & 4 & 3 & $75-85$ & 26.9 & $1.69 \times 10^{3}$ & \\
\hline U1365 & B & 4 & 4 & $75-85$ & 28.4 & $4.96 \times 10^{2}$ & \\
\hline U1365 & B & 4 & 5 & $75-85$ & 29.9 & $2.04 \times 10^{3}$ & \\
\hline U1365 & B & 4 & 6 & $75-85$ & 31.4 & $4.96 \times 10^{2}$ & \\
\hline U1365 & B & 4 & 7 & $25-30$ & 32.4 & $3.34 \times 10^{2}$ & \\
\hline U1365 & B & 5 & 1 & $75-85$ & 33.4 & $2.26 \times 10^{2}$ & \\
\hline U1365 & B & 5 & 2 & $75-85$ & 34.9 & $3.08 \times 10^{3}$ & \\
\hline U1365 & B & 5 & 3 & $75-85$ & 36.4 & $1.03 \times 10^{3}$ & \\
\hline U1365 & B & 5 & 4 & $75-85$ & 37.9 & $6.84 \times 10^{2}$ & \\
\hline U1365 & B & 5 & 5 & $65-75$ & 39.3 & $1.43 \times 10^{3}$ & $S$ \\
\hline U1365 & B & 5 & 6 & $75-85$ & 40.9 & $6.64 \times 10^{2}$ & $\mathrm{H}$ \\
\hline U1365 & B & 5 & 7 & $63-73$ & 42.3 & $6.67 \times 10^{2}$ & $\mathrm{H}$ \\
\hline U1365 & B & 8 & 2 & $40-50$ & 65.5 & $1.33 \times 10^{4}$ & \\
\hline U1365 & B & 8 & 3 & $55-65$ & 66.6 & $8.70 \times 10^{1}$ & \\
\hline U1365 & B & 9 & 1 & $140-149$ & 68.4 & $5.17 \times 10^{3}$ & \\
\hline U1365 & B & 9 & 2 & $40-50$ & 69.0 & $1.01 \times 10^{4}$ & \\
\hline U1365 & B & 9 & 3 & $40-50$ & 70.5 & $3.86 \times 10^{2}$ & \\
\hline U1365 & B & 9 & 4 & $40-50$ & 72.0 & $2.76 \times 10^{3}$ & \\
\hline U1365 & B & 9 & 5 & $40-50$ & 73.5 & $3.60 \times 10^{3}$ & \\
\hline U1365 & B & 9 & 6 & $50-60$ & 74.7 & $4.99 \times 10^{3}$ & \\
\hline U1365 & B & 9 & 6 & $50-60$ & 75.1 & $2.10 \times 10^{3}$ & \\
\hline U1365 & B & 9 & 6 & $50-60$ & 75.6 & $4.55 \times 10^{3}$ & \\
\hline U1366 & D & 1 & 2 & $40-50$ & 2.0 & $2.27 \times 10^{4}$ & \\
\hline U1366 & D & 1 & 3 & $40-50$ & 3.5 & $1.05 \times 10^{4}$ & \\
\hline U1366 & D & 1 & 4 & $50-60$ & 5.1 & $5.23 \times 10^{4}$ & \\
\hline U1366 & D & 1 & 5 & $40-50$ & 6.5 & $5.10 \times 10^{4}$ & \\
\hline U1366 & D & 1 & 6 & $40-50$ & 8.0 & $1.43 \times 10^{5}$ & \\
\hline U1366 & D & 1 & 7 & $20-30$ & 9.0 & $1.71 \times 10^{4}$ & \\
\hline U1366 & D & 2 & 1 & $40-50$ & 9.9 & $3.36 \times 10^{4}$ & \\
\hline U1366 & D & 2 & 2 & $40-50$ & 11.4 & $8.32 \times 10^{3}$ & \\
\hline U1366 & D & 2 & 3 & $40-50$ & 12.9 & $1.11 \times 10^{4}$ & \\
\hline U1366 & D & 2 & 4 & $40-50$ & 14.4 & $5.56 \times 10^{2}$ & \\
\hline U1366 & D & 2 & 6 & $40-50$ & 17.2 & $2.75 \times 10^{3}$ & \\
\hline U1366 & $\mathrm{F}$ & 2 & 2 & $60-70$ & 7.7 & $9.15 \times 10^{2}$ & \\
\hline U1366 & $\mathrm{F}$ & 2 & 4 & $60-70$ & 10.7 & $1.44 \times 10^{4}$ & \\
\hline U1366 & $\mathrm{F}$ & 3 & 1 & $40-50$ & 14.5 & $5.44 \times 10^{3}$ & $\mathrm{H}$ \\
\hline U1366 & $\mathrm{F}$ & 3 & 2 & $40-50$ & 16.0 & $6.67 \times 10^{3}$ & \\
\hline U1366 & $\mathrm{F}$ & 3 & 3 & $40-50$ & 17.5 & $4.99 \times 10^{3}$ & \\
\hline U1366 & $\mathrm{F}$ & 3 & 4 & $40-50$ & 19.0 & $8.74 \times 10^{3}$ & \\
\hline U1366 & $\mathrm{F}$ & 3 & 5 & $40-50$ & 20.5 & $5.75 \times 10^{3}$ & \\
\hline U1366 & $\mathrm{F}$ & 3 & 6 & $40-50$ & 22.0 & $3.55 \times 10^{3}$ & \\
\hline U1366 & $\mathrm{F}$ & 3 & 7 & $30-41$ & 23.4 & $2.48 \times 10^{2}$ & \\
\hline
\end{tabular}




$\begin{array}{ll}\text { U1366 } & F \\ \text { U1366 } & F \\ \text { U1366 } & F \\ \text { U1366 } & F \\ \text { U1366 } & F \\ \text { U1366 } & F \\ \text { U1366 } & F\end{array}$

$\begin{array}{cc}40-50 & 24.0 \\ 40-50 & 25.3 \\ 40-50 & 25.5 \\ 40-50 & 27.0 \\ 0-10 & 28.1 \\ 50-59 & 29.5 \\ 40-50 & 30.1\end{array}$

$5.61 \times 10^{3}$

$\mathrm{H}$

$5.67 \times 10^{3}$

$9.81 \times 10^{3}$

$5.49 \times 10^{3}$

$7.18 \times 10^{3}$

$8.84 \times 10^{3}$

$7.47 \times 10^{5}$

H

H

\begin{tabular}{|c|c|c|c|c|c|c|c|}
\hline U1367 & C & 1 & 1 & $10-20$ & 0.2 & $2.31 \times 10^{5}$ & $\mathrm{~S}$ \\
\hline U1367 & C & 1 & 2 & $60-70$ & 2.2 & $1.91 \times 10^{5}$ & \\
\hline U1367 & $\mathrm{C}$ & 1 & 3 & $60-70$ & 3.7 & $3.84 \times 10^{4}$ & \\
\hline U1367 & $C$ & 1 & 4 & $60-70$ & 5.2 & $9.56 \times 10^{5}$ & \\
\hline U1367 & C & 1 & 5 & $60-70$ & 6.7 & $1.06 \times 10^{3}$ & $\mathrm{~S}$ \\
\hline U1367 & $\mathrm{C}$ & 2 & 1 & $60-70$ & 7.9 & $2.82 \times 10^{3}$ & \\
\hline U1367 & C & 2 & 2 & $60-70$ & 9.4 & $1.89 \times 10^{3}$ & \\
\hline U1367 & C & 2 & 3 & $60-70$ & 10.9 & $5.90 \times 10^{3}$ & \\
\hline U1367 & C & 2 & 4 & $60-70$ & 12.4 & $1.70 \times 10^{3}$ & \\
\hline U1367 & C & 2 & 5 & $60-70$ & 13.9 & $1.43 \times 10^{3}$ & \\
\hline U1367 & C & 2 & 6 & $60-70$ & 15.4 & $4.90 \times 10^{3}$ & \\
\hline U1367 & C & 2 & 7 & $50-60$ & 16.8 & $4.79 \times 10^{3}$ & \\
\hline U1367 & $C$ & 3 & 1 & $50-60$ & 17.3 & $1.82 \times 10^{4}$ & \\
\hline U1367 & C & 3 & 2 & $0-5$ & 18.2 & $5.00 \times 10^{3}$ & \\
\hline U1367 & $C$ & 3 & 3 & $60-70$ & 20.4 & $4.38 \times 10^{3}$ & \\
\hline U1367 & $C$ & 3 & 4 & $60-70$ & 21.9 & $2.23 \times 10^{3}$ & \\
\hline U1367 & C & 3 & 6 & $0-5$ & 23.6 & $6.04 \times 10^{3}$ & $\mathrm{~F}$ \\
\hline U1367 & D & 2 & 4 & $50-60$ & 12.5 & $4.31 \times 10^{5}$ & $\mathrm{~S}$ \\
\hline U1367 & $\mathrm{D}$ & 3 & 1 & $80-90$ & 17.8 & $2.42 \times 10^{4}$ & $\mathrm{~S}$ \\
\hline U1367 & D & 3 & 2 & $10-20$ & 18.6 & $1.28 \times 10^{6}$ & $\mathrm{~S}$ \\
\hline U1367 & D & 3 & 3 & $10-20$ & 20.1 & $7.45 \times 10^{4}$ & $\mathrm{~S}$ \\
\hline U1367 & $\mathrm{D}$ & 3 & 4 & $80-90$ & 22.3 & $2.23 \times 10^{3}$ & $\mathrm{~S}$ \\
\hline U1367 & D & 3 & 5 & $80-90$ & 23.8 & $3.34 \times 10^{2}$ & \\
\hline U1367 & D & 3 & 6 & $10-20$ & 24.6 & $2.85 \times 10^{3}$ & \\
\hline U1368 & C & 1 & 1 & $10-15$ & 0.1 & $1.13 \times 10^{6}$ & \\
\hline U1368 & $\mathrm{C}$ & 1 & 2 & $60-70$ & 2.2 & $4.04 \times 10^{6}$ & \\
\hline U1368 & C & 1 & 3 & $60-70$ & 3.7 & $5.45 \times 10^{6}$ & \\
\hline U1368 & $C$ & 1 & 4 & $60-70$ & 5.2 & $1.05 \times 10^{5}$ & \\
\hline U1368 & C & 1 & 5 & $40-50$ & 6.5 & $1.85 \times 10^{5}$ & \\
\hline U1368 & C & 1 & 6 & $10-20$ & 7.7 & $1.04 \times 10^{5}$ & \\
\hline U1368 & C & 2 & 1 & $50-60$ & 8.6 & $3.43 \times 10^{3}$ & $S$ \\
\hline U1368 & C & 2 & 2 & $60-70$ & 10.2 & $5.07 \times 10^{3}$ & $\mathrm{~S}$ \\
\hline U1368 & C & 2 & 3 & $60-70$ & 11.7 & $2.40 \times 10^{3}$ & $\mathrm{~S}$ \\
\hline U1368 & $C$ & 2 & 4 & $60-70$ & 13.2 & $7.85 \times 10^{3}$ & $\mathrm{~S}$ \\
\hline U1368 & $\mathrm{C}$ & 2 & 5 & $60-70$ & 14.7 & $2.19 \times 10^{3}$ & \\
\hline
\end{tabular}




\begin{tabular}{|c|c|c|c|c|c|c|c|}
\hline U1368 & $C$ & 2 & 6 & $10-20$ & 15.6 & $1.31 \times 10^{5}$ & $\mathrm{H}$ \\
\hline U1369 & C & 1 & 1 & $15-20$ & 0.2 & $4.83 \times 10^{5}$ & $\mathrm{H}$ \\
\hline U1369 & C & 1 & 2 & $50-60$ & 2.1 & $6.18 \times 10^{3}$ & $\mathrm{H}$ \\
\hline U1369 & C & 1 & 3 & $50-60$ & 3.6 & $9.93 \times 10^{2}$ & \\
\hline U1369 & C & 1 & 4 & $50-60$ & 5.1 & $2.85 \times 10^{3}$ & \\
\hline U1369 & C & 2 & 1 & $50-60$ & 6.6 & $2.41 \times 10^{3}$ & \\
\hline U1369 & $\mathrm{C}$ & 2 & 2 & $50-60$ & 8.1 & $1.71 \times 10^{3}$ & \\
\hline U1369 & $C$ & 2 & 3 & $50-60$ & 9.6 & $2.16 \times 10^{3}$ & \\
\hline U1369 & C & 2 & 4 & $50-60$ & 11.1 & $9.99 \times 10^{2}$ & \\
\hline U1369 & $C$ & 2 & 5 & $50-60$ & 12.6 & $5.34 \times 10^{3}$ & \\
\hline U1369 & $C$ & 2 & 6 & $50-60$ & 14.1 & $1.24 \times 10^{2}$ & \\
\hline U1369 & C & 2 & 7 & $45-54$ & 15.5 & $1.09 \times 10^{4}$ & \\
\hline U1369 & E & 2 & 6 & $90-100$ & 15.3 & $1.38 \times 10^{4}$ & \\
\hline
\end{tabular}

\begin{tabular}{|c|c|c|c|c|c|c|c|}
\hline U1370 & $E$ & 1 & 1 & $35-42.5$ & 0.4 & $9.55 \times 10^{5}$ & $S$ \\
\hline U1370 & $E$ & 1 & 2 & $30-40$ & 1.9 & $1.88 \times 10^{5}$ & \\
\hline U1370 & $E$ & 1 & 3 & $30-40$ & 3.4 & $1.07 \times 10^{5}$ & \\
\hline U1370 & $E$ & 1 & 4 & $147-152$ & 6.0 & $8.67 \times 10^{4}$ & \\
\hline U1370 & $E$ & 2 & 1 & $135-140$ & 7.6 & $2.62 \times 10^{3}$ & \\
\hline U1370 & $E$ & 2 & 2 & $135-140$ & 9.1 & $8.31 \times 10^{3}$ & \\
\hline U1370 & $E$ & 2 & 3 & $135-140$ & 10.6 & $2.19 \times 10^{3}$ & \\
\hline U1370 & $E$ & 2 & 4 & $125-130$ & 12.0 & $7.58 \times 10^{3}$ & \\
\hline U1370 & $E$ & 2 & 5 & $135-140$ & 13.6 & $1.81 \times 10^{4}$ & \\
\hline U1370 & $E$ & 2 & 6 & $118-123$ & 14.9 & $4.53 \times 10^{3}$ & \\
\hline U1370 & $E$ & 3 & 1 & $135-140$ & 17.1 & $8.19 \times 10^{3}$ & \\
\hline U1370 & $E$ & 3 & 2 & $135-140$ & 18.6 & $6.78 \times 10^{3}$ & \\
\hline U1370 & $E$ & 3 & 3 & $135-140$ & 20.1 & $2.11 \times 10^{3}$ & \\
\hline U1370 & $E$ & 3 & 4 & $125-130$ & 21.5 & $5.11 \times 10^{3}$ & \\
\hline U1370 & $E$ & 3 & 5 & $135-140$ & 23.1 & $2.12 \times 10^{3}$ & \\
\hline U1370 & $E$ & 3 & 6 & 53-58 & 23.8 & $2.76 \times 10^{3}$ & \\
\hline U1370 & $E$ & 4 & 1 & $135-140$ & 26.6 & $3.79 \times 10^{3}$ & \\
\hline U1370 & $E$ & 4 & 2 & $135-140$ & 28.1 & $1.43 \times 10^{3}$ & \\
\hline U1370 & $E$ & 4 & 3 & $135-140$ & 29.6 & $1.03 \times 10^{3}$ & \\
\hline U1370 & $E$ & 4 & 4 & $125-130$ & 31.0 & $2.78 \times 10^{3}$ & \\
\hline U1370 & $E$ & 4 & 5 & $135-140$ & 32.6 & $6.91 \times 10^{2}$ & \\
\hline U1370 & $E$ & 5 & 1 & $135-140$ & 36.1 & $8.61 \times 10^{3}$ & \\
\hline U1370 & $E$ & 5 & 2 & $129-134$ & 37.5 & $5.67 \times 10^{3}$ & \\
\hline U1370 & $E$ & 5 & 3 & $135-140$ & 39.0 & $6.05 \times 10^{3}$ & \\
\hline U1370 & $E$ & 5 & 4 & $125-130$ & 40.4 & $7.71 \times 10^{3}$ & \\
\hline U1370 & $E$ & 5 & 5 & $135-140$ & 42.0 & $8.93 \times 10^{3}$ & \\
\hline U1370 & $E$ & 5 & 6 & 55-60 & 42.7 & $5.97 \times 10^{3}$ & \\
\hline U1370 & $E$ & 6 & 1 & $135-140$ & 45.6 & $2.48 \times 10^{3}$ & \\
\hline U1370 & $E$ & 6 & 2 & $124-134$ & 47.0 & $3.91 \times 10^{3}$ & \\
\hline
\end{tabular}




\begin{tabular}{|c|c|c|c|c|c|c|c|}
\hline U1370 & $\mathrm{E}$ & 6 & 3 & $135-140$ & 48.5 & $1.85 \times 10^{3}$ & \\
\hline U1370 & $E$ & 6 & 4 & $135-140$ & 50.0 & $1.47 \times 10^{3}$ & \\
\hline U1370 & $\mathrm{E}$ & 6 & 5 & $95-100$ & 51.1 & $7.23 \times 10^{3}$ & \\
\hline U1370 & $\mathrm{E}$ & 8 & 2 & $135-140$ & 58.3 & $2.06 \times 10^{3}$ & $\mathrm{H}$ \\
\hline U1370 & $\mathrm{E}$ & 8 & 3 & $135-140$ & 59.8 & $5.08 \times 10^{3}$ & $\mathrm{~F}$ \\
\hline U1370 & $E$ & 8 & 4 & $125-130$ & 61.2 & $7.13 \times 10^{3}$ & $\mathrm{~F}$ \\
\hline U1370 & $\mathrm{E}$ & 8 & 5 & $135-140$ & 62.8 & $3.74 \times 10^{3}$ & $\mathrm{~F}$ \\
\hline U1370 & $E$ & 9 & 1 & $135-140$ & 63.5 & $6.57 \times 10^{3}$ & $\mathrm{~F}$ \\
\hline U1370 & $E$ & 8 & 6 & $135-140$ & 64.3 & $6.57 \times 10^{3}$ & $\mathrm{~F}$ \\
\hline U1370 & $E$ & 9 & 2 & $135-140$ & 65.0 & $4.43 \times 10^{3}$ & $\mathrm{~F}$ \\
\hline U1370 & $\mathrm{F}$ & 5 & 3 & $135-140$ & 39.6 & $4.87 \times 10^{3}$ & \\
\hline U1370 & $\mathrm{F}$ & 5 & 4 & $135-140$ & 41.1 & $4.06 \times 10^{3}$ & \\
\hline U1370 & $\mathrm{F}$ & 5 & 5 & $135-140$ & 42.6 & $3.90 \times 10^{3}$ & \\
\hline U1370 & $\mathrm{F}$ & 6 & 2 & $135-140$ & 47.6 & $5.50 \times 10^{3}$ & \\
\hline U1370 & $\mathrm{F}$ & 6 & 3 & $135-140$ & 49.1 & $5.68 \times 10^{3}$ & \\
\hline U1370 & $\mathrm{F}$ & 6 & 4 & $135-140$ & 50.6 & $4.41 \times 10^{3}$ & \\
\hline U1370 & $\mathrm{F}$ & 6 & 5 & $135-140$ & 52.1 & $6.17 \times 10^{3}$ & \\
\hline U1370 & $\mathrm{F}$ & 7 & 1 & $135-140$ & 55.6 & $3.65 \times 10^{3}$ & \\
\hline U1370 & $\mathrm{F}$ & 7 & 2 & $135-140$ & 57.1 & $1.45 \times 10^{3}$ & \\
\hline U1370 & $\mathrm{F}$ & 7 & 3 & $135-140$ & 58.6 & $2.29 \times 10^{3}$ & \\
\hline U1370 & $\mathrm{F}$ & 7 & 4 & $125-130$ & 60.0 & $3.94 \times 10^{3}$ & \\
\hline U1370 & $\mathrm{F}$ & 7 & 5 & $135-140$ & 61.6 & $7.09 \times 10^{3}$ & \\
\hline U1370 & $\mathrm{F}$ & 7 & 6 & $135-140$ & 63.1 & $2.19 \times 10^{3}$ & \\
\hline U1371 & $E$ & 1 & 1 & $30-40$ & 0.4 & $4.91 \times 10^{5}$ & $\mathrm{H}$ \\
\hline U1371 & $E$ & 1 & 2 & $30-40$ & 1.9 & $2.37 \times 10^{5}$ & \\
\hline U1371 & $E$ & 1 & 3 & $30-40$ & 3.4 & $4.65 \times 10^{5}$ & \\
\hline U1371 & $E$ & 1 & 4 & $135-140$ & 5.9 & $1.29 \times 10^{6}$ & \\
\hline U1371 & $E$ & 1 & 5 & $135-140$ & 7.4 & $1.48 \times 10^{5}$ & \\
\hline U1371 & $E$ & 1 & 6 & $52-57$ & 8.0 & $2.33 \times 10^{5}$ & \\
\hline U1371 & $\mathrm{E}$ & 2 & 1 & $135-140$ & 9.6 & $1.25 \times 10^{5}$ & \\
\hline U1371 & $E$ & 2 & 2 & $135-140$ & 11.1 & $9.06 \times 10^{4}$ & \\
\hline U1371 & $E$ & 2 & 3 & $135-140$ & 12.6 & $1.24 \times 10^{5}$ & \\
\hline U1371 & $E$ & 2 & 4 & $135-140$ & 14.1 & $5.41 \times 10^{4}$ & \\
\hline U1371 & $E$ & 2 & 5 & $90-95$ & 15.1 & $1.07 \times 10^{5}$ & \\
\hline U1371 & $E$ & 3 & 2 & $135-140$ & 20.6 & $1.05 \times 10^{5}$ & \\
\hline U1371 & $E$ & 3 & 3 & $125-130$ & 22.0 & $1.38 \times 10^{5}$ & \\
\hline U1371 & $E$ & 3 & 4 & $135-140$ & 23.6 & $1.27 \times 10^{5}$ & \\
\hline U1371 & $E$ & 3 & 5 & $115-120$ & 24.9 & $6.93 \times 10^{4}$ & \\
\hline U1371 & $E$ & 3 & 6 & $41-46$ & 25.4 & $9.82 \times 10^{4}$ & \\
\hline U1371 & $E$ & 4 & 1 & $135-140$ & 28.6 & $3.45 \times 10^{5}$ & \\
\hline U1371 & $E$ & 4 & 2 & $135-140$ & 30.1 & $4.05 \times 10^{3}$ & \\
\hline U1371 & $E$ & 4 & 3 & $135-140$ & 31.6 & $2.85 \times 10^{4}$ & \\
\hline U1371 & $E$ & 4 & 4 & $135-140$ & 33.1 & $2.38 \times 10^{4}$ & \\
\hline U1371 & $E$ & 4 & 5 & $115-120$ & 34.4 & $1.34 \times 10^{4}$ & \\
\hline
\end{tabular}




\begin{tabular}{|c|c|c|c|c|c|c|c|}
\hline U1371 & $\mathrm{E}$ & 5 & 1 & $135-140$ & 38.1 & $6.20 \times 10^{3}$ & \\
\hline U1371 & E & 5 & 2 & $135-140$ & 39.6 & $2.85 \times 10^{3}$ & \\
\hline U1371 & E & 5 & 3 & $135-140$ & 41.1 & $4.07 \times 10^{3}$ & \\
\hline U1371 & E & 5 & 4 & $135-140$ & 42.6 & $8.15 \times 10^{3}$ & \\
\hline U1371 & E & 5 & 5 & $60-65$ & 43.3 & $1.53 \times 10^{4}$ & \\
\hline U1371 & $\mathrm{E}$ & 6 & 3 & $135-140$ & 50.6 & $7.95 \times 10^{3}$ & $\mathrm{H}$ \\
\hline U1371 & $\mathrm{E}$ & 6 & 5 & $135-140$ & 53.6 & $5.16 \times 10^{3}$ & \\
\hline U1371 & E & 7 & 1 & $135-140$ & 57.1 & $5.11 \times 10^{3}$ & $\mathrm{H}$ \\
\hline U1371 & $\mathrm{E}$ & 7 & 2 & $135-140$ & 58.6 & $3.61 \times 10^{3}$ & \\
\hline U1371 & E & 7 & 3 & $125-130$ & 60.0 & $5.20 \times 10^{3}$ & $\mathrm{H}$ \\
\hline U1371 & $E$ & 7 & 5 & $135-140$ & 63.1 & $2.84 \times 10^{3}$ & \\
\hline U1371 & E & 8 & 1 & $135-140$ & 66.6 & $2.81 \times 10^{3}$ & $\mathrm{H}$ \\
\hline U1371 & $\mathrm{E}$ & 8 & 3 & $135-140$ & 69.6 & $5.76 \times 10^{3}$ & \\
\hline U1371 & E & 8 & 5 & $135-140$ & 72.6 & $6.91 \times 10^{3}$ & \\
\hline U1371 & E & 9 & 2 & $135-140$ & 76.5 & $1.33 \times 10^{4}$ & \\
\hline U1371 & E & 9 & 4 & $135-140$ & 79.5 & $2.17 \times 10^{3}$ & \\
\hline U1371 & E & 9 & 6 & $135-140$ & 82.5 & $2.25 \times 10^{3}$ & \\
\hline U1371 & E & 10 & 1 & $135-140$ & 85.6 & $2.79 \times 10^{3}$ & \\
\hline U1371 & E & 10 & 3 & $135-140$ & 88.6 & $6.97 \times 10^{3}$ & \\
\hline U1371 & E & 10 & 5 & $135-140$ & 91.6 & $1.13 \times 10^{4}$ & \\
\hline U1371 & E & 11 & 1 & $135-140$ & 95.1 & $2.35 \times 10^{4}$ & \\
\hline U1371 & E & 11 & 3 & $125-130$ & 98.0 & $2.32 \times 10^{3}$ & \\
\hline U1371 & E & 11 & 5 & $135-140$ & 101.1 & $9.46 \times 10^{3}$ & \\
\hline U1371 & E & 12 & 2 & $135-140$ & 106.1 & $6.86 \times 10^{2}$ & \\
\hline U1371 & E & 12 & 3 & $125-130$ & 107.5 & $4.30 \times 10^{3}$ & \\
\hline U1371 & $E$ & 12 & 4 & $108-118$ & 108.8 & $6.66 \times 10^{3}$ & \\
\hline U1371 & E & 13 & 1 & $135-140$ & 114.1 & $3.10 \times 10^{3}$ & \\
\hline U1371 & E & 13 & 2 & $135-140$ & 115.6 & $6.89 \times 10^{3}$ & \\
\hline U1371 & E & 13 & 3 & $125-130$ & 117.0 & $3.02 \times 10^{3}$ & \\
\hline U1371 & $\mathrm{E}$ & 13 & 4 & $135-140$ & 118.6 & $7.68 \times 10^{3}$ & \\
\hline U1371 & E & 13 & 5 & $135-140$ & 120.1 & $1.99 \times 10^{3}$ & \\
\hline U1371 & $E$ & 13 & 6 & $135-140$ & 121.6 & $1.43 \times 10^{4}$ & \\
\hline U1371 & $\mathrm{E}$ & 13 & 7 & $24-29$ & 122.0 & $5.19 \times 10^{3}$ & \\
\hline U1371 & $\mathrm{E}$ & 14 & 1 & $135-140$ & 123.6 & $1.08 \times 10^{4}$ & \\
\hline U1371 & E & 14 & 2 & $135-140$ & 125.1 & $3.79 \times 10^{3}$ & \\
\hline U1371 & $\mathrm{E}$ & 14 & 3 & $30-40$ & 125.6 & $4.78 \times 10^{3}$ & \\
\hline U1371 & E & 14 & 5 & $30-40$ & 128.6 & $3.32 \times 10^{2}$ & \\
\hline U1371 & $E$ & 14 & 6 & $51-56$ & 130.2 & $1.57 \times 10^{4}$ & $\mathrm{~F}$ \\
\hline
\end{tabular}


277 Table 3. Vertical distribution of $\mathrm{O}_{2}$ reaction rates (net respiration) at Expedition 329 $278 \quad$ sites.

\begin{tabular}{|c|c|c|c|c|}
\hline Interval & $\begin{array}{l}\text { \# data points in } \\
\text { each zone }\end{array}$ & Depth & $\begin{array}{l}\text { Reaction rate } \pm 1^{*} \text { sigma } \\
\left(\mathrm{mol} \mathrm{O}_{2} / \mathrm{cm}^{3} / \mathrm{yr}\right)\end{array}$ & $\begin{array}{c}\text { Net respiration rate per cell } \\
\qquad 1^{*} \text { sigma } \\
\left(\mathrm{mol} \mathrm{O}_{2} / \text { cell/yr }\right)\end{array}$ \\
\hline \multicolumn{5}{|c|}{ Site U1365 } \\
\hline 1 & 4 & $0.25-2.18$ & $-8.68 \mathrm{E}-11 \pm 3.68 \mathrm{E}-11$ & $-3.06 \mathrm{E}-16 \pm 3.76 \mathrm{E}-16$ \\
\hline 2 & 5 & $2.38-4.69$ & $4.63 \mathrm{E}-12 \pm 1.86 \mathrm{E}-11$ & $1.97 \mathrm{E}-16 \pm 7.95 \mathrm{E}-16$ \\
\hline 3 & 6 & $4.89-8.76$ & $-1.52 \mathrm{E}-11 \pm 8.49 \mathrm{E}-12$ & $-6.83 E-16 \pm 3.82 E-16$ \\
\hline \multirow{4}{*}{4} & \multirow{4}{*}{25} & $8.95-12.81$ & $-9.28 \mathrm{E}-13 \pm 6.13 \mathrm{E}-12$ & $-9.98 \mathrm{E}-17 \pm 6.60 \mathrm{E}-16$ \\
\hline & & $24.95-27.20$ & $-9.28 \mathrm{E}-13 \pm 1.27 \mathrm{E}-12$ & $-5.46 \mathrm{E}-16 \pm 7.45 \mathrm{E}-16$ \\
\hline & & $27.95-30.95$ & $-9.28 \mathrm{E}-13 \pm 3.84 \mathrm{E}-12$ & $-7.33 \mathrm{E}-16 \pm 3.10 \mathrm{E}-16$ \\
\hline & & $31.18-37.95$ & $-9.28 \mathrm{E}-13 \pm 1.95 \mathrm{E}-12$ & $-8.99 \mathrm{E}-16 \pm 2.15 \mathrm{E}-16$ \\
\hline \multirow{3}{*}{5} & \multirow{3}{*}{13} & $64.45-65.95$ & $-8.45 \mathrm{E}-12 \pm 2.52 \mathrm{E}-12$ & $-1.26 \mathrm{E}-15 \pm 1.80 \mathrm{E}-15$ \\
\hline & & $69.04-71.05$ & $-8.45 \mathrm{E}-12 \pm 1.96 \mathrm{E}-12$ & $-1.52 \mathrm{E}-15 \pm 1.13 \mathrm{E}-15$ \\
\hline & & $74.45-75.05$ & $-8.45 \mathrm{E}-12 \pm 1.96 \mathrm{E}-12$ & $-2.96 \mathrm{E}-15 \pm 1.30 \mathrm{E}-15$ \\
\hline \multicolumn{5}{|c|}{ Site U1366 } \\
\hline 1 & 7 & $0.25-2.26$ & $-6.27 \mathrm{E}-11 \pm 2.22 \mathrm{E}-11$ & $-2.77 \mathrm{E}-15 \pm 1.44 \mathrm{E}-15$ \\
\hline \multirow{5}{*}{2} & \multirow{5}{*}{22} & $2.41-2.87$ & $-2.67 \mathrm{E}-12 \pm 1.25 \mathrm{E}-11$ & $-8.49 \mathrm{E}-17 \pm 4.04 \mathrm{E}-17$ \\
\hline & & $3.03-8.27$ & $-2.67 \mathrm{E}-12 \pm 2.36 \mathrm{E}-12$ & $-3.93 \mathrm{E}-17 \pm 5.29 \mathrm{E}-17$ \\
\hline & & $8.43-11.82$ & $-2.67 \mathrm{E}-12 \pm 2.88 \mathrm{E}-12$ & $-1.45 \mathrm{E}-16 \pm 1.79 \mathrm{E}-16$ \\
\hline & & $11.98-14.29$ & $-2.67 \mathrm{E}-12 \pm 9.78 \mathrm{E}-12$ & $-2.75 \mathrm{E}-16 \pm 1.01 \mathrm{E}-16$ \\
\hline & & $14.45-14.76$ & $-2.67 \mathrm{E}-12 \pm 9.84 \mathrm{E}-12$ & $-8.90 \mathrm{E}-16 \pm 3.44 \mathrm{E}-16$ \\
\hline \multicolumn{5}{|c|}{ Site U1367 } \\
\hline \multirow{2}{*}{1} & \multirow{2}{*}{8} & $0.05-0.5$ & $-5.34 \mathrm{E}-10 \pm 1.70 \mathrm{E}-10$ & $-2.13 \mathrm{E}-15 \pm 7.89 \mathrm{E}-16$ \\
\hline & & $0.65-1.10$ & $-5.34 \mathrm{E}-10 \pm 1.28 \mathrm{E}-10$ & $-2.79 \mathrm{E}-15 \pm 1.71 \mathrm{E}-15$ \\
\hline \multirow{4}{*}{2} & \multirow{4}{*}{19} & $1.70-3.35$ & $-1.55 \mathrm{E}-12 \pm 1.73 \mathrm{E}-11$ & $-8.11 \mathrm{E}-18 \pm 3.11 \mathrm{E}-18$ \\
\hline & & $3.50-3.80$ & $-1.55 \mathrm{E}-12 \pm 1.65 \mathrm{E}-11$ & $-3.12 \mathrm{E}-18 \pm 3.34 \mathrm{E}-18$ \\
\hline & & $3.95-5.75$ & $-1.55 \mathrm{E}-12 \pm 5.36 \mathrm{E}-12$ & $-3.24 \mathrm{E}-18 \pm 1.27 \mathrm{E}-18$ \\
\hline & & $5.90-18.8$ & $-1.55 \mathrm{E}-12 \pm 9.67 \mathrm{E}-13$ & $-1.04 \mathrm{E}-17 \pm 2.72 \mathrm{E}-17$ \\
\hline \multicolumn{5}{|c|}{ Site U1369 } \\
\hline 1 & 6 & $0.3-1.32$ & $-1.72 \mathrm{E}-10 \pm 6.35 \mathrm{E}-12$ & $-3.56 \mathrm{E}-16 \pm 2.49 \mathrm{E}-16$ \\
\hline 2 & 5 & $1.44-4.98$ & $4.43 \mathrm{E}-12 \pm 6.35 \mathrm{E}-13$ & $1.33 \mathrm{E}-15 \pm 1.06 \mathrm{E}-15$ \\
\hline 3 & 14 & $5.10-14.00$ & $-3.59 \mathrm{E}-12 \pm 1.51 \mathrm{E}-13$ & $-1.69 \mathrm{E}-15 \pm 1.42 \mathrm{E}-15$ \\
\hline \multicolumn{5}{|c|}{ Site U1370 } \\
\hline 1 & 15 & $0.05-1.64$ & $-3.38 \mathrm{E}-10 \pm 2.45 \mathrm{E}-12$ & $-5.19 \mathrm{E}-16 \pm 5.61 \mathrm{E}-16$ \\
\hline 2 & 12 & $1.81-6.23$ & $7.64 \mathrm{E}-13 \pm 7.42 \mathrm{E}-13$ & $7.88 \mathrm{E}-18 \pm 7.74 \mathrm{E}-18$ \\
\hline 3 & 12 & $6.40-15.22$ & $-5.04 \mathrm{E}-12 \pm 5.32 \mathrm{E}-13$ & $-6.98 \mathrm{E}-16 \pm 5.74 \mathrm{E}-16$ \\
\hline 4 & 13 & $15.40-37.29$ & $-2.39 \mathrm{E}-12 \pm 1.22 \mathrm{E}-13$ & $-6.08 \mathrm{E}-16 \pm 4.18 \mathrm{E}-16$ \\
\hline 5 & 37 & $37.46-68.00$ & $-3.28 \mathrm{E}-13 \pm 3.92 \mathrm{E}-14$ & $-6.98 \mathrm{E}-17 \pm 3.14 \mathrm{E}-17$ \\
\hline
\end{tabular}


280 Fig 1. Dissolved $\mathrm{O}_{2}$ concentrations vs. dissolved $\mathrm{NO}_{3}{ }^{-}$concentrations at Sites U1365-

281 U1370. Symbol colors as in manuscript Fig 1. Most data closely match the

282 Redfield ratio [black line ${ }^{33}$ ]. Data from the two sites with thinnest sediment

283 (youngest) basement (U1367 and U1368) fall below the Redfield line because

284 their $\mathrm{O}_{2}$ concentrations are primarily controlled by $\mathrm{O}_{2}$ loss to the underlying

285 basement. Data from below 30 mbsf at U1370 fall below Redfield at low $\mathrm{O}_{2}$

286 concentrations because $\mathrm{NO}_{3}{ }^{-}$concentrations at greater depth are affected by loss

287 to the underlying basement. These non-Redfield losses (of $\mathrm{O}_{2}$ to the basement at

$288 \mathrm{U} 1367$ and $\mathrm{U} 1368$, and $\mathrm{NO}_{3}{ }^{-}$to basement at U1370) are consistent with non-

289 heterotrophic (lithotrophic) microbial processes in the basement.

290 Fig 2. Regions where we predict dissolved $\mathrm{O}_{2}$ and aerobic activity to persist from

291 seafloor to igneous basement, based on sediment thickness and mean sediment

292 accumulation rates. (A) Sediment accumulation rate and sediment thickness at

293 sites where $\mathrm{O}_{2}$ does or does not penetrate to basement. Sediment thicknesses at

294 these sites were determined by direct measurement (drilling or piston-coring to

295 basement). Red dots indicate sites where dissolved $\mathrm{O}_{2}$ diffusively penetrates the

296 entire sediment column (up to $75 \mathrm{mbsf})^{1,21,24}$. Black dots indicate sites where

297 dissolved $\mathrm{O}_{2}$ disappears in $\mathrm{cm}$ to meters below the seafloor ${ }^{1,11,21-24}$. Yellow dots

298 indicate sites where dissolved $\mathrm{O}_{2}$ penetrates more than 7 to $34 \mathrm{mbsf}$ and may

299 penetrate to basement but $\mathrm{O}_{2}$ content is not fully characterized throughout the

300 entire sediment column ${ }^{21,22,24}$. (B) Global map predicted from relationships in

301 (A), combined with mean sediment thicknesses and mean sediment accumulation

302 rates defined by standard global maps of sediment thickness ${ }^{17,18}$ and seafloor 
$303 \quad$ age $^{19}$ averaged over fine-minute grids.

304 The blue areas in $2 \mathrm{~A}$ and $2 \mathrm{~B}$ are defined by combinations of sediment

305 thickness and mean sediment accumulation where $\mathrm{O}_{2}$ is known to penetrate the

306 entire sediment sequence; they represent a minimum estimate of the area over

307 which dissolved $\mathrm{O}_{2}$ permeates the entire sediment sequence and the upper

308 basement (9\% of global seafloor in 2B). The green areas are defined by

309 combinations where $\mathrm{O}_{2}$ may penetrate the entire column but chemical data

310 resolution is too low to be certain (13\% of seafloor in $2 \mathrm{~B})$. The orange areas mark

311 combinations of mean sediment accumulation and sediment thickness for which

$312 \mathrm{O}_{2}$ may penetrate to basement but there are no $\mathrm{O}_{2}$ or $\mathrm{NO}_{3}{ }^{-}$data (3\% of seafloor in

3132 2B). Because estimated mean sediment thicknesses in five-minute grids

314 throughout the ocean ${ }^{17,18}$ often differ from local sediment thicknesses determined

315 by drilling or piston-coring to basement, not all sites where $\mathrm{O}_{2}$ penetrates to

316 basement in $2 \mathrm{~A}$ are located in the blue areas in 2B. The combined yellow, green

317 and blue areas in both $2 \mathrm{~A}$ and $2 \mathrm{~B}$ are defined by the combinations of mean

318 sedimentation rates and sediment thicknesses from the standard sediment-

319 thickness maps ${ }^{17,18}$ that include all locations where dissolved $\mathrm{O}_{2}$ is known to

320 locally penetrate the entire sediment column (34\% of seafloor in $2 B$ ). The sum of

321 the blue, green, yellow and orange regions represents a maximum estimate of the

322 area over which dissolved $\mathrm{O}_{2}$ permeates the entire sediment sequence from the

323 seafloor ( $37 \%$ of total seafloor in $2 \mathrm{~B}$ ). These collective regions broadly include all

324 areas of abyssal clay and slowly accumulating carbonate ooze in the world ocean.

325 
326 Fig 1.

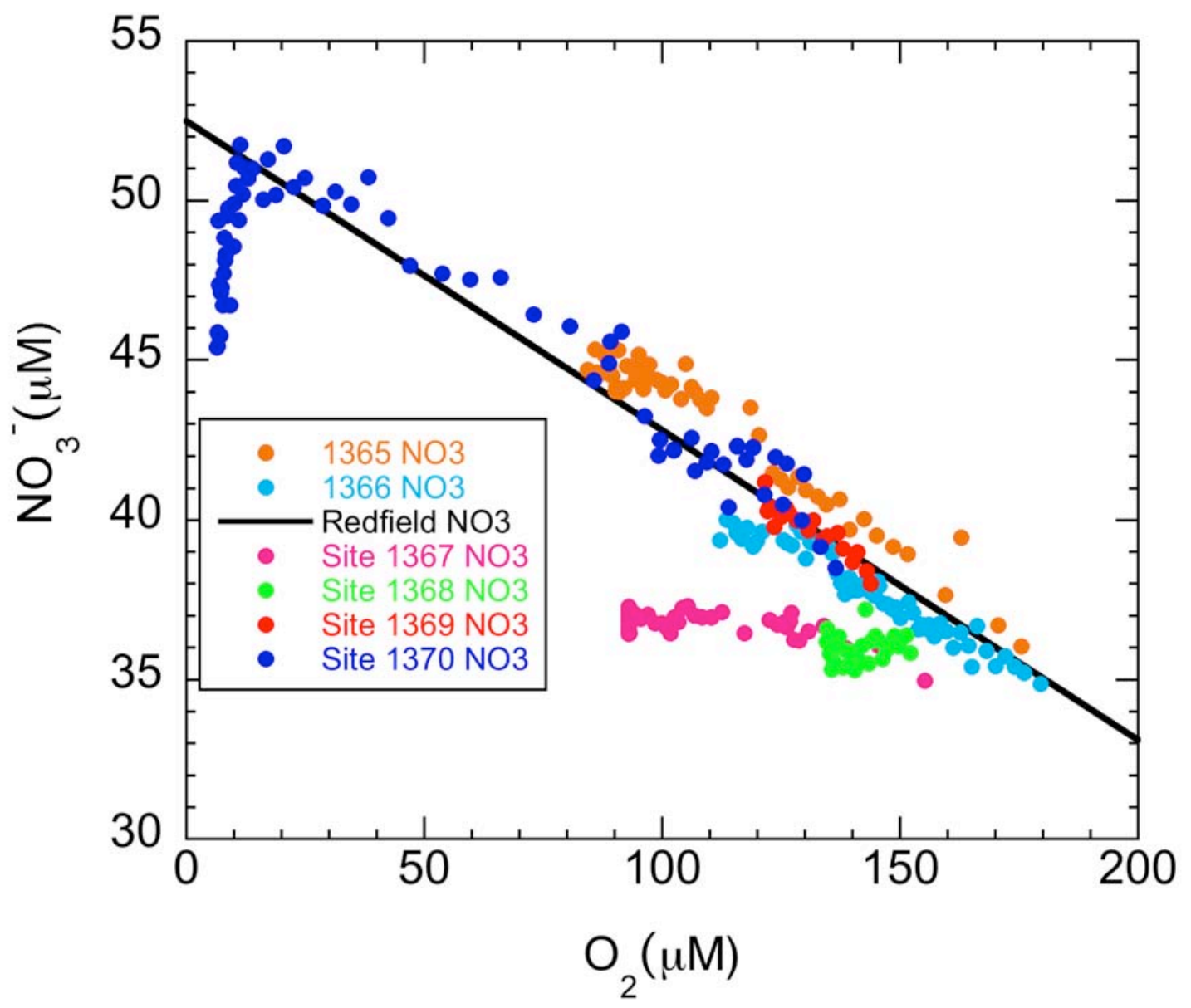

327

328 
329 Fig 2A.

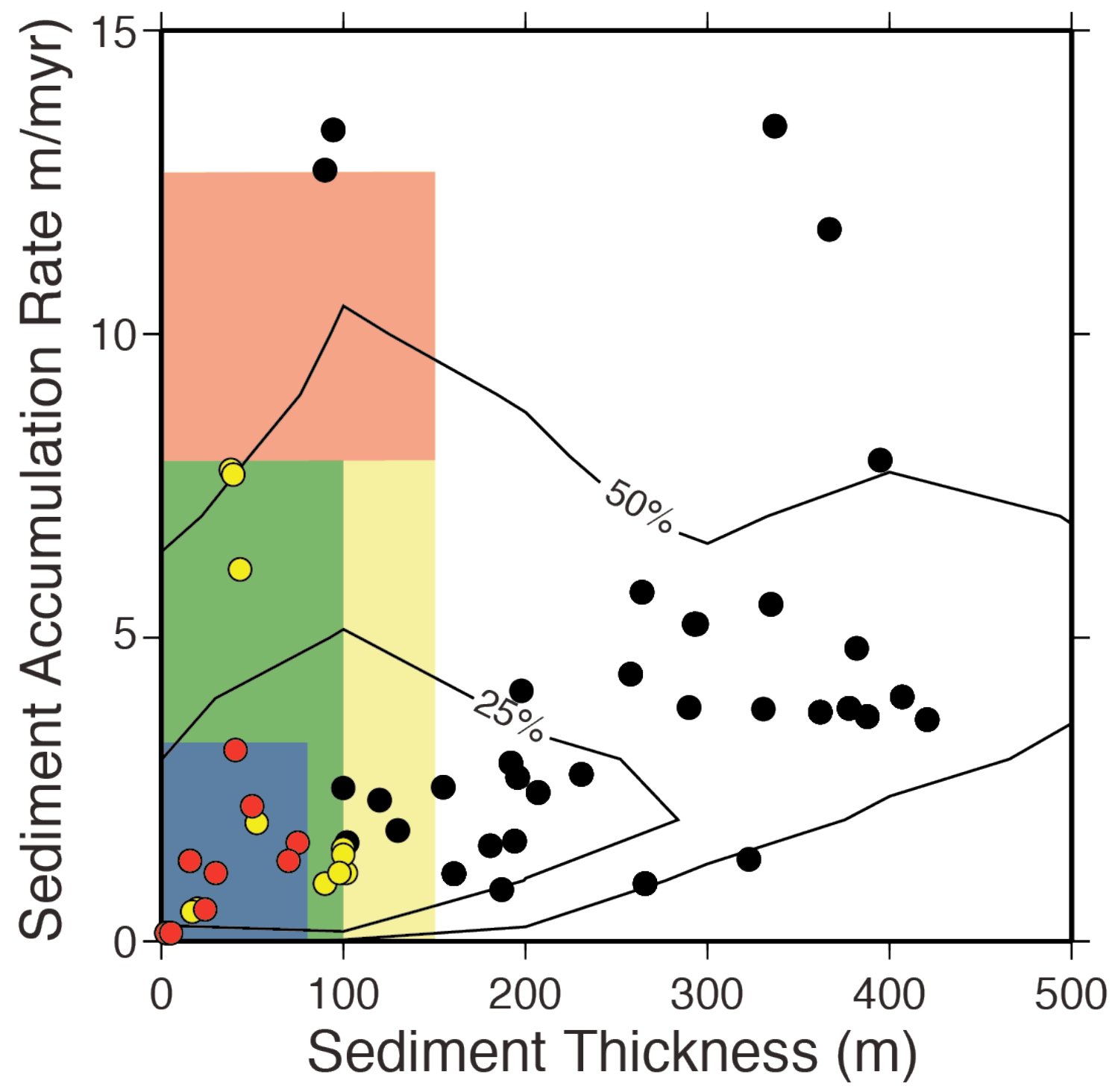

330

331 
332 Fig 2B.

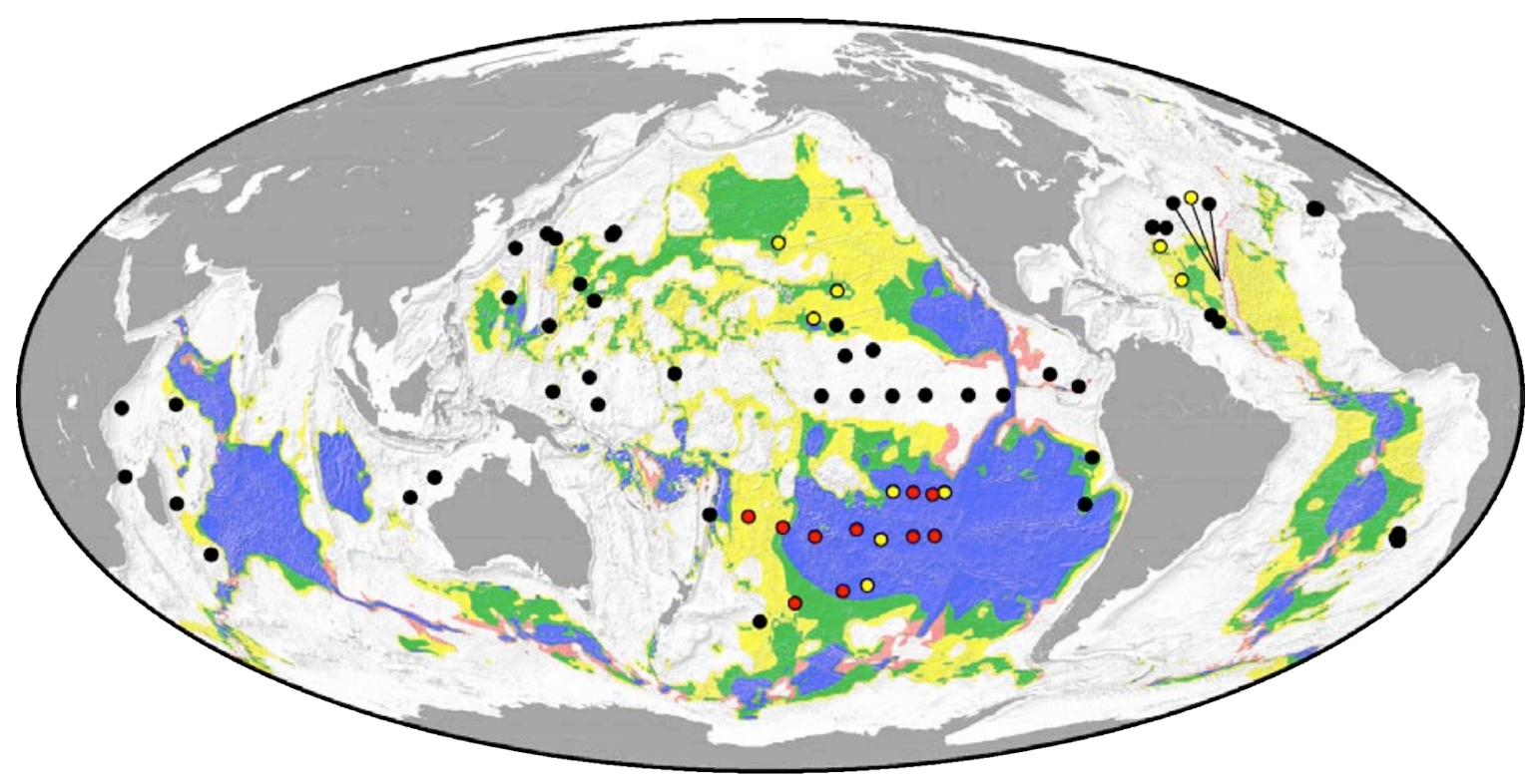

333 